\title{
CULTURA, LINGUAGEM E FONOAUDIOLOGIA: UMA ESCUTA DO DISCURSO FAMILIAR NO CONTEXTO DA SAÚDE PÚBLICA.
}

STELLA MARIS BRUM LOPES

Dissertação apresentada ao Departamento de Práticas de Saúde da Faculdade de Saúde Pública da Universidade de São Paulo, para obtenção do Título de Mestre em Saúde Pública.

Orientador: PROF. DR. RUBENS DE CAMARGO FERREIRA ADORNO.

São Paulo 
Aos meus pais que com muito carinho e dedicação, mostraram como unir teoria, prática e emoção. E também por mostrarem com seu exemplo que o serviço público é um espaço para a construção de ações éticas e comprometidas.

Às mulheres e aos profissionais de saúde de Zimbros por partilharem suas histórias com uma estrangeira. 


\section{Agradecimentos}

Ao Prof. Dr. Rubens de Camargo Ferreira Adorno, pela amizade, serenidade e confiança com que conduziu o processo de orientação. E principalmente pelo estimulo para que eu sempre buscasse os recursos necessários para realização de um trabalho que respeitasse a subjetividade de todos os envolvidos.

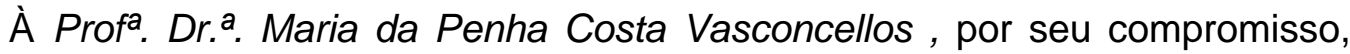
paciência, crítica aguda mas generosa, cumplicidade e carinho com que me acompanhou durante todo o mestrado e, fundamentalmente, por sua sensibilidade na nossa relação, cujo continente auxiliou nas minhas reflexões pessoais e profissionais.

Aos membros da Pré banca professores Dr. Arnaldo Augusto Franco de Siqueira e Dr. a Yolanda Flores e Silva, pela importância de suas sugestões no processo de elaboração deste trabalho.

Em especial às fonoaudiólogas Prof ${ }^{a}$. Dr. ${ }^{\underline{a}}$ Dóris Ruth Lewis e Prof ${ }^{a}$. Dr ${ }^{\underline{a}}$ Suzana Magalhães Maia, também membros da banca, pelo respeito, disponibilidade e preciosa interlocução sobre este trabalho, suas críticas e sugestões foram muito importantes.

Aos oceanógrafos Prof. Dr. Marcus Polette e Rodrigo Medeiros pelo carinho, paciência e confiança com que me inseriram no trabalho em comunidades pesqueiras.

À Secretaria de Saúde de Bombinhas, em especial a enfermeira Lucimar e a toda equipe de profissionais da Unidade de Saúde pela acolhida e liberdade na realização do trabalho de campo.

À Fga. Msc. Evanice do Carmo pela confiança e incentivo durante toda minha trajetória na UNIVALI, e em especial por sempre estimular nossa criatividade e ousadia no exercício profissional.

Às amigas Isabel e Indiara companheiras de estudo, descobertas, devaneios e inquietações pela presença constante e amorosa em todo este trajeto. E ao Chico pela paciência e seu jeito todo especial de dar força ao trio.

À amiga Denise Terçariol Cordeiro com quem partilho diretamente as questões que envolveram este trabalho pelo carinho, amizade e grande apoio.

À Sandra pelo carinho, amorosidade e atenção com que tem me acompanhado durante todo este tempo. 
Aos amigos da turma de mestrado que através da convivência bem humorada exercitou a difícil arte de aprender a lidar com as diferenças. Especialmente à Aline, companheira serena e constante de orientações, pelo carinho e amizade.

À Ivelise e ao Alberto pela escuta amorosa e firme que auxiliou a ultrapassar e aprender com cada fase deste trabalho.

Aos amigos, Matarezi, José Luís, Irene, Elisa, Vanusa, Maione, Celina, Valdete, Bonilha, Marlova, Karina, Fernando, Rosa cada um com seu jeito todo especial de ser ajudou a tornar mais fácil e tranquilo este caminho. Obrigado pela paciência e compreensão nas ausências e "furos".

Aos meus alunos e ex-alunos, pelo privilégio de participar de suas questões e descobertas.

À ProPPEx e a Coordenação do Curso de Fonoaudiologia da Univali pelo incentivo e confiança que sempre depositaram na elaboração e acompanhamento dos Projetos de Extensão que geraram este trabalho.

À equipe de extensão do bairro Votorantim pela oportunidade de trabalhar com uma equipe que sempre manteve o respeito pela subjetividade de cada um de seus membros e pela compreensão durante a etapa final do

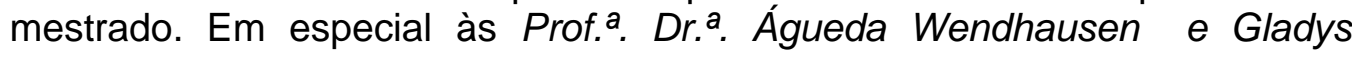
Brodensen pela sensibilidade, conhecimento e dedicação na coordenação desta equipe.

Às amigas do Setor de Fonoaudiologia Preventiva e da Clínica de Fonoaudiologia do Instituo de Fonoaudiologia da Univali, pelo clima de incentivo, companheirismo e confiança que norteia o nosso trabalho.

Aos funcionários do Instituto de Fonoaudiologia, em especial a Rose, Rosane, Ivana e Cíntia pela compreensão e apoio nos momentos de atropelo.

À Elba, Leandro, Mário, Tânia, Everaldo, Scarlet, pelo apoio - telefonemas, xerox, revisões, scanner - e alivio que sua disponibilidade e sensibilidade gerou no final deste trabalho. 
Lopes S.M.B. Cultura, linguagem e fonoaudiologia: uma escuta do discurso familiar no contexto da Saúde Pública. São Paulo: 2001. [Dissertação de Mestrado - Faculdade de Saúde Pública da USP]

\section{RESUMO}

Este estudo buscou compreender o contexto cultural que envolve as práticas das mães residentes na comunidade pesqueira de Zimbros em Bombinhas, Santa Catarina e foi construído a partir do diálogo entre Fonoaudiologia, Saúde Pública e as Ciências Sociais. O caminho metodológico contou com contribuições da Etnografia, utilizando-se na pesquisa a observação participante realizada na sala de espera da Unidade de Saúde do bairro. A partir da análise dos textos dos diários de campo, observei a importância de construir-se uma escuta em relação à população e explorar mais o espaço da Unidade de Saúde como um espaço comunicativo para que a população possa ressignificar as suas práticas. As práticas das mães refletem a maneira como a comunidade entende as questões de linguagem. Neste local há um silêncio em relação às questões de linguagem que estão atreladas ao desejo da criança de falar, a espera do tempo certo para falar, sendo mais evidentes para as mães as questões atreladas ao uso de chupeta, à amamentação e/ou alimentação. A função das mães circula entre atender os desejos do filho ou repassar normas de conduta. Portanto, a Fonoaudiologia deve aprofundar as questões relacionadas à linguagem e cultura; construir formas alternativas de abordar a população, buscando situações dialógicas e que possam auxiliar outros profissionais a valorizarem as falas das mães .

Descritores: Família. Fonoaudiologia, Linguagem, Cultura, Saúde Pública. 
Lopes S.M.B. Culture, language and speech therapy: a hearing of the family discourse in the Public Health context. São Paulo: 2001. [Master's Dissertation - Public Health School at the University of São Paulo].

\section{SUMMARY}

This study has sought to understand the cultural context which involves the practice of the mothers living in the fishing community of Zimbros in Bombinhas, Santa Catarina State, and was developed from the dialog among Speech Therapy, Public Health, and Social Sciences. The methodological path featured the contributions from Etnography, by using, in the research, the participant observation carried out in the waiting room of the neighborhood's Health Department. From the analyses of the field diary texts, I have noticed the importance of developing a hearing related to the population and futher exploring the Health Department space as a communicative space so that the population may give a new meaning to their practices. The mothers' practices reflect the way in which the community understands the language issues. In this place, there is a silence with reference to the language issues which are linked to the child's desire to speak, the right waiting period to speak, where the issues which are more evident to the mothers included the use of pacifiers, breastfeeding and/our feeding. The mothers' roles range from meeting the child's wishes to passing on behavior rules. Therefore, Speech Therapy must further study the issues related to language and culture, develop alternative ways of approaching the population, seeking dialogical situations that may help other professionals to value the mothers' speeches.

Keywords: Family, Speech and Language Therapy, Language, Culture, Public Health. 


\section{ÍNDICE}

1. Introdução: Caminhos e Descaminhos na construção 1 de uma atuação em Saúde Pública

Escolhendo Zimbros

Construindo um Estudo

2. Capítulo 1: Caminho Metodológico

Do discurso ao campo: as contradições do pesquisador

3. Capítulo 2: Linguagem e Cultura

Zimbros: espaço de continuidade e descontinuidade

O nativo e o estrangeiro

Recriando Identidades na Fala dos Moradores

4. Capítulo 3: Entrelaçando Família, Cultura e Linguagem

Como nossos Pais: aprendendo a ser mãe

Do desejo da mãe ao desejo da criança: o caso da chupeta

Fala: um dos lugares do desejo da criança

5. Capítulo 4: Unidade de Saúde: campo de ressignificações

6. Considerações Finais

7. Referências Bibliográficas

Anexo

Termo de Consentimento 


\section{INTRODUÇÃO: Caminhos e Descaminhos na construção de uma atuação em Saúde Pública}

O importante e bonito do mundo é isso: que as pessoas não estão sempre iguais, ainda não foram terminadas mas que estão sempre mudando. Afinam e desafinam.

Guimarães

Rosa 
O interesse em estudar a dimensão cultural nas práticas das mães em relação à linguagem das crianças de 0 a 2 anos é resultado de um processo reflexivo sobre minha trajetória como fonoaudióloga em direção ao desenvolvimento de uma escuta do discurso familiar.

Trajetória iniciada no final da década de 80 , na APAE de Brusque, quando comecei a trabalhar com mães e famílias de crianças de 0 a 3 anos que frequentavam o programa de estimulação precoce. Apesar da vontade de trabalhar com os pais, sentia-me muito limitada e contraditória nas intervenções, pois buscava ora indicar atividades voltadas para a normalização da criança, ora ser um dos profissionais que auxiliaria no processo de aceitação da limitação do filho.

Nesta fase, ser fonoaudióloga envolvia a realização de avaliação e intervenção na criança e em sua família. Este entendimento como sinalizam Gomes $^{1}$ e Rubino ${ }^{2}$, apesar de procurar entender a família, tem como objetivo final transformar a maneira como a família, e mais especificamente a mãe,

\footnotetext{
${ }^{1}$ GOMES, Ivone D. E quando a família vem ao caso. In: MARCHESAN, Irene e col. Tópicos em Fonoaudiologia, 1995. São Paulo:Lovise,1995. Volume II, p. 483 - 496.

${ }^{2}$ RUBINO, Rejane. Entre ver e ler: o olhar do fonoaudiólogo em questão. In: LIER-DE VITTO, Maria Francisca. Fonoaudiologia: no sentido da linguagem. São Paulo: Cortez,1994. p. 69 90 .
} 
vêem a criança. Neste sentido, fica implícita a visão de que este conhecimento era distorcido, sendo "negado" o saber da família sobre seus membros. ${ }^{3}$

Esta visão foi ainda mais reforçada durante a especialização em Educação Especial, na qual pude conhecer inúmeras escalas de desenvolvimento infantil e as fases pelas quais os pais passam para aceitarem um filho portador de necessidades especiais.

Se teoricamente a ação estava fundamentada, por que as mães não seguiam as indicações? Por que apenas quando realizávamos dinâmicas de grupo elas relatavam suas dificuldades, dúvidas, temores e sentimentos em relação a seus filhos?

Eram questões difíceis de serem respondidas naquele momento, principalmente porque a concepção de linguagem que norteava o trabalho era de linguagem vista como comunicação. ${ }^{4}$ Nesta lógica, a falha deveria estar nos aspectos emocionais que envolviam esta situação comunicativa (entre profissional e mãe), busquei, então, em uma formação em Terapia Familiar Sistêmica, entender estas falhas.

\footnotetext{
${ }^{3}$ A postura dos profissionais de saúde como donos do saber tem sido discutida em várias áreas da saúde. Ver: BOLTANSKI, Luc. As classes sociais e o corpo. Tradução de Regina Machado. Rio de Janeiro: Graal,1979. PROST, A . Fronteiras e espaços privados. In: História da vida privada 5: da primeira guerra aos nossos dias. São Paulo: Cia das Letras, 1992, p. 61-154. COSTA, Jurandir F. Ordem médica e norma familiar. $2^{2}$ edição. Rio de Janeiro: Graal Editora, 1983.

${ }^{4}$ Neste modelo para existir uma comunicação efetiva há um receptor e um emissor. Assim, o sujeito deverá ter um aparato perceptual e cognitivo íntegro para conseguir se comunicar em um ambiente favorável. Há uma idéia de transparência envolvendo a linguagem, cercada também por um enfoque multicausal para suas alterações.
} 
Apesar de relacionar-se com modelos descritivos de comunicação, a teoria sistêmica também estava discutindo a validade destes modelos, redimensionando seu fazer através de uma postura menos objetiva (positivista) em relação à realidade. O terapeuta não mais assumia o papel de "consertador" das famílias, mas sim daquele que busca construir junto com a família novas significações para as questões familiares, assumindo desta forma, não ter o controle do processo terapêutico, já que este passa a ser entendido como uma atividade dialógica.

E é neste processo que acabo conotando positivamente ações que pareciam não pertencer à Fonoaudiologia, isto é, saber mais dos sentimentos e sensações da família sobre seus membros, ouvi-la sem necessariamente ter de prescrever alguma conduta, e ainda o fato de não buscar apenas aspectos orgânicos para as questões apresentadas.

Nesta época, junto com uma equipe, fui encarregada de estruturar um programa de prevenção que teria como objetivos principais: acompanhar o desenvolvimento das crianças de zero a três anos do município de Brusque; valorizar a importância de observar-se o desenvolvimento das crianças através de campanhas educativas e implantar programas de atenção a gestantes e recém-nascidos no contexto hospitalar.

\footnotetext{
${ }^{5}$ Termo utilizado por Molina - Loza ao caracterizar os modelos terapêuticos utilizados no enfoque sistêmico, apresentando-os em três metáforas: o que vai consertar a família, o técnico de um time e o que vai realizar um concerto com a família. Ver: MOLINA - LOZA, Carlos A . Destino Familiar, Desatino Terapêutico. Belo Horizonte: ArteSã, 1996. p. 259 - 271.
} 
Inicia-se, deste modo, o caminho para trabalhos em comunidade. A aproximação teórica realizada é em direção à medicina preventiva por meio da organização de ações a partir da análise da história natural da doença. ${ }^{6}$

Cresce assim, a necessidade de teorizar a respeito já que nesta mesma época além de mudanças profissionais ${ }^{7}$, há uma revisão conceitual dentro da Fonoaudiologia crescendo as discussões sobre a noção de linguagem vista como comunicação. Trabalhos como os de Lewis, Masson, Pereira e Maia, ${ }^{8}$ evidenciam as dificuldades enfrentadas pela Fonoaudiologia que a partir dos anos 80 vive uma crise de paradigmas. Esta crise expressa-se nas dificuldades para estruturação dos programas de atuação fonoaudiológica no serviço público.

A maioria das propostas volta-se para a cura dos indivíduos, e as atuações de promoção da saúde caracterizam-se por palestras e atividades educativas voltadas à modificação de hábitos e comportamentos individuais.

\footnotetext{
${ }^{6}$ Modelo proposto por Leavell e Clark (1976) no qual saúde e doença são um processo em que há uma história natural da doença, sendo possível a elaboração de intervenções que interceptem esta história desde o período pré-patogênico. Ver: LEAVELL, H.R. e CLARK, E.G. Medicina Preventiva. São Paulo: Mc Graw-Hill,1977.

${ }^{7}$ Em meados de 1992 inicio minha carreira como docente na UNIVALI. Atuei como docente e supervisora de estágios na disciplina de Fonoaudiologia Preventiva. Atualmente sou responsável pela disciplina de Fonoaudiologia em Saúde Pública.

${ }^{8}$ LEWIS, Dóris R. A prática fonoaudiológica em serviços de atenção primária à saúde em São Paulo: um estudo de representações socias. São Paulo; 1996. [ Tese de Doutorado Faculdade de Saúde Pública da USP]. MASSON, Maria Lúcia V. É melhor prevenir ou remediar? Um estudo sobre a construção do conceito de prevenção em fonoaudiologia. São Paulo; 1995. [ Dissertação de Mestrado - Pontifícia Universidade Católica de São Paulo]. MAIA, Suzana M. Implicações sociais do trabalho fonoaudiológico na atenção primária à saúde. In: BEFI, Débora (org.). Fonoaudiologia na atenção primária à saúde. São Paulo: Lovise,1997.p.37-41.
} 
Andrade ao adaptar o modelo da história natural da doença começa por definir que:

as doenças da comunicação humana não se caracterizam por alterações laboratoriais, não saram pela ingestão de drogas, não provocam dor, nem levam 0 indivíduo à morte. $O$ doente fonoaudiológico sofre de uma manifestação patológica que altera sua saúde fundamentalmente pelo sofrimento, pela perda ou insucesso da capacidade fundamental e estrita de sua espécie, que é a de processar a produção e expressão de suas ideologias e de poder, de pela palavra criar e transformar o mundo. ${ }^{9}$

A autora diferencia claramente a fonoaudiologia das outras áreas da saúde, possibilitando o levantamento de algumas questões: se somos tão diferentes das outras áreas será que basta adaptar os modelos da medicina preventiva? O sofrimento do "doente fonoaudiológico" está diretamente ligado a questões relacionais? Portanto, é possível excluir os aspectos culturais e sociais da nossa prática?

Ao rediscutir sua formação e atuação, os fonoaudiólogos reconhecem que os sintomas que aparecem na doença fonoaudiológica mostram um acontecimento no movimento da linguagem que não se submete

\footnotetext{
${ }^{9}$ ANDRADE, Claúdia R. F. Problemas Fonoaudiológicos. In: CONCEIÇÃO, J.A.N. (org.) Saúde escolar: a criança, a vida e a escola. São Paulo: Sarvier, 1994. Monografias Médicas, série pediatria, volume XXXIII, p.153.
} 
diretamente ao bom funcionamento orgânico. Pereira ${ }^{10}$ afirma que "diluir o sintoma fonoaudiológico no sintoma da Medicina, ou da Psicologia, ou de qualquer outra disciplina, é confundir a natureza dos objetos de investigação e tratamento."

Apesar destas reflexões, na prática das unidades de saúde, continuam prevalecendo as ações norteadas pela prevenção primária, secundária e terciária, já com a identificação de que se precisava incorporar mais conhecimentos sobre saúde pública a estas ações. E são estas ações que abrem espaço para reconhecer-se novas questões como os limites da atuação neste modelo (história natural) numa profissão em que ainda são incipientes os estudos epidemiológicos e também questionamentos em relação a propostas prontas direcionadas às questões de linguagem.

Estas questões ampliaram-se durante as atividades do Programa Universidade Solidária ${ }^{11}$ que foram eminentemente educativas e de capacitação de agentes de saúde e professores através de uma abordagem interdisciplinar.

\footnotetext{
${ }^{10}$ PEREIRA, Cristiane M. Fonoaudiologia em atenção primária à saúde: a questão do sintoma na clínica fonoaudiológica. São Paulo:1998. [ Dissertação de Mestrado - Pontifícia Universidade Católica de São Paulo]. p. 64.

${ }^{11}$ Programa desenvolvido pelo Governo Federal inicialmente em cidades carentes do Nordeste. As atividades são realizadas por uma equipe de dez alunos, coordenada por um professor que permanece durante um mês em um município, realizando atividades de educação em saúde e participação comunitária. Como professora da UNIVALI participei do projeto piloto em 1996 na cidade de Elesbão Veloso(Piauí) e em 1997 na cidade de Carneiros (Alagoas). A UNIVALI sempre privilegiou na composição das equipes alunos de vários cursos, não havendo restrições. As equipes que coordenei eram compostas por alunos dos cursos de Jornalismo, Direito, Enfermagem, Oceanografia, Pedagogia, Fonoaudiologia e Odontologia.
} 
Identifiquei-me como profissional de saúde e pude reconhecer a necessidade de se desenvolver um processo de "escuta" em relação às comunidades.

Nas atividades realizadas no Nordeste e dentro das próprias equipes a necessidade de escuta era óbvia já que as diferenças eram evidentes. Aceitávamos facilmente que quem sabia da sua realidade eram eles. Ao voltar e propor atividades para as Comunidades Pesqueiras, ficou mais difícil encarar estas diferenças, tornando-se recorrentes questões como: Qual o meu papel como profissional de saúde? Que utilidade têm as ações dos profissionais para a população? Como um fonoaudiólogo pode trabalhar com promoção da saúde?

A oportunidade de cursar o mestrado em Saúde Pública ${ }^{12}$ permitiu um salto na atuação profissional, pois ao ter maior conhecimento sobre as políticas de saúde, conceitos e estudos epidemiológicos, pude sedimentar minha prática, hoje muito mais ligada à dinâmica das unidades de saúde e às necessidades da comunidade. Tornou-se cada vez mais evidente a necessidade de romper com um modelo pautado na doença e trabalhar com propostas mais articuladas à realidade, que não será nunca estanque ou única.

\footnotetext{
${ }^{12}$ Mestrado Inter-institucional realizado a partir de convênio entre a Faculdade de Saúde Pública /USP - SP e a Universidade do Vale do Itajaí, iniciado em maio de 1998.
} 
Hoje entendo que o mestrado foi uma quebra em conceitos arraigados, abrindo espaço para a compreensão de que respostas prontas e propostas aplicáveis não existem. Neste processo fui capturada pelas questões levantadas pelas Ciências Sociais, articulando Saúde Pública, Fonoaudiologia e Sociedade.

Articulação possível se encarar o fonoaudiólogo como profissional interessado em conhecer o homem inserido em seu contexto de vida a partir da linguagem. Linguagem esta tida como constitutiva ${ }^{13}$ do sujeito, "na qual o pensamento não precede a palavra, mas realiza-se e descobre-se nela." ${ }^{14}$

Entendendo nesse momento que as Ciências Sociais, "possuem instrumental teórico-metodológico de importância fundamental para que os profissionais de saúde possam ter uma visão critica dos seus papéis profissionais." " Já que seus estudos, enfatizam a "importância de compreender a vida cotidiana, as necessidades e as visões de mundo das pessoas que

\footnotetext{
${ }^{13}$ A linguagem é tida como constitutiva por ser uma experiência intersubjetiva que tem seus limites dados pelo seu uso prático. FAUSTINO, Silvia. O lugar da linguagem na filosofia do século XX. In: FABBRINI, Regina e OLIVEIRA, Sérgio L. (org.) Interpretação. São Paulo: Lovise, 1998. p. 96.

${ }^{14}$ ALVES, Paulo C. e RABELO, Míriam C. Repensando os estudos sobre representações e práticas em saúde/doença. Rio de Janeiro: Fiocruz-Relume Dumará,1998. Antropologia as saúde: traçando identidade e explorando fronteiras; p. 119

${ }^{15}$ NUNES, Everardo D. As ciências sociais e a saúde: o pensamento recente de alguns pesquisadores. In: CANESQUI, Ana Maria. Dilemas e desafios das ciências sociais na saúde coletiva. São Paulo: Hucitec-ABRASCO, 1995. p. 56.
} 
vivem em diferentes comunidades, de diferentes backgrounds culturais e sociais". ${ }^{16}$

Este enfoque envolve a noção de cultura tida como uma criação coletiva de idéias, símbolos e valores para os quais uma sociedade define para si mesma o bom, mau etc. A cultura realiza-se porque os seres humanos são capazes da linguagem. ${ }^{17} \mathrm{E}$ é a busca da aproximação entre cultura, linguagem e fonoaudiologia que este estudo procura evidenciar.

E é no encontro entre profissionais e comunidade que poderemos entender como

os indivíduos vivem a realidade biológica enquanto trabalhada pela cultura. As representações ${ }^{18}$ de corpo, saúde e doença são uma realidade advinda da experiência dos indivíduos. O corpo surge então não apenas como objeto de representação mas como fundamento de nossa subjetividade. As práticas de cuidados do corpo são orientadas por uma lógica que resulta da experiência social e, com base nesta,

\footnotetext{
${ }^{16}$ HELMAN, Cecil G. Cultura, saúde e doença. $2^{a}$ ed. Porto Alegre: Artes Médicas, 1994.p.13.

${ }^{17}$ CHAUÍ,Marilena. Convite à Filosofia. São Paulo: Ática, 1994, p. 288-296.

${ }^{18}$ Representação Social será entendida como categorias do pensamento que explicam a realidade, justificando-a. O indivíduo nesta perspectiva é visto como portador da cultura e de valores socialmente dados, e ele poderá informar sobre a ação social de seu grupo, sendo necessário levar-se em conta que essas informações são limitadas pelos valores de cada indivíduo. A linguagem é a mediação privilegiada para a compreensão das representações sociais. MINAYO, Maria Cecília. O conceito de representações sociais dentro da sociologia clássica. In: GUARESCHI, Pedrinho e JOVCHELOVITCH, Sandra. Textos em representações sociais. $4^{\mathrm{a}}$ ed. Petropólis: Vozes,1998. p. 89-111.
} 
produzem-se interpretações que adquirem o significado a partir de processos compartilhados no cotidiano." ${ }^{19}$

Buscando articular as questões desencadeadas pelo trabalho com famílias no contexto da saúde pública, pretendo neste estudo, compreender o lugar dado ao desenvolvimento da linguagem por mães de uma comunidade pesqueira, indagando a partir de que negociações este lugar foi construído. Esta indagação parte do reconhecimento de que este lugar constrói-se num processo de permanente negociação com o mundo e de que o conhecimento do senso comum segue uma lógica que soma aspectos do conhecimento especializado num movimento reflexivo.

\section{Escolhendo Zimbros...}

O primeiro contato com o município foi como turista em meados da década de 80 , neste período o município que fica no litoral centro-norte de Santa Catarina pertencia a Porto Belo.

\footnotetext{
${ }^{19}$ FERREIRA, Jaqueline. Cuidados do Corpo em vila de classe popular. In: DUARTE, Luiz Fernando D.(org.). Doença, sofrimento, perturbação: perspectivas etnográficas. Rio de Janeiro: FIOCRUZ, 1998, p.55.
} 
As impressões iniciais sobre o lugar relacionaram-se à beleza da paisagem, cor e transparência das águas, e à grande dificuldade de acesso, pois as estradas não pavimentadas eram intransponíveis nos dias de chuva.

$\mathrm{Na}$ alta temporada eram comuns enormes filas no trajeto, na maioria das vezes porque havia carros estragados na estrada. Ao cruzar o morro, chegava-se à praia de Bombas e logo após Bombinhas, praias nas quais os moradores já tinham um contato maior com os turistas, não sendo muito significativa a presença de pescadores. Ir a Zimbros ou Canto Grande significava uma aventura, pois os caminhos eram difíceis e as comunidades bem isoladas, assim, o turismo restringia-se a piqueniques.

Em meados da década de 90, após minha primeira participação no Programa Universidade Solidária, surgiu a oportunidade de construir uma outra relação com Bombinhas, a partir da estruturação de um trabalho junto ao Laboratório de Planejamento da Paisagem Costeira do Curso de Oceanografia da UNIVALI. Esta parceria foi resultado de um projeto de caracterização das comunidades pesqueiras artesanais do litoral centro-norte catarinense e que identificou várias necessidades da população em relação à área de saúde, envolvendo desde a assistência até trabalho de informação em saúde.

Como tinha experiência em trabalho com comunidades fui indicada pela coordenadora do curso de Fonoaudiologia a organizar uma proposta de atuação voltada às treze comunidades pesqueiras atingidas pelo curso de oceanografia. Iniciei também uma caracterização da comunidade, 
objetivando: conhecer os hábitos e crenças da população em relação à audição, fala, alimentação e linguagem, identificando, a partir do discurso da população, os fatores de risco para a saúde fonoaudiológica.

Como resultados observou-se :

- abandono do hábito de contar histórias locais, substituindo-as por televisão ou leitura da bíblia;

- uso de simpatias;

- prática da automedicação;

- desinformação quanto às ações que promovem melhoria da saúde fonoaudiológica;

- queixas auditivas indicativas de quadros de PAIR (perda auditiva induzida pelo ruído) e otite média;

- busca tardia de recursos terapêuticos para os problemas de linguagem (7 ou 8 anos), tendo conseqüências para o processo de alfabetização da criança.

A partir destes resultados associados aos obtidos pelos pesquisadores do curso de Oceanografia organizou-se uma intervenção que enfatizasse atividades de educação em saúde, regionalizando a proposta do programa Universidade Solidária. Nestas atividades houve baixa participação 
da comunidade, realizando-se apenas os cursos de saúde da mulher e de reciclagem do lixo.

Os próprios participantes durante a avaliação referiram-se à baixa participação:

Pena que não tinha quase ninguém. Acho que perderam uma ótima chance, já que não é sempre que temos gente disponível para essas coisas... (Maria)

Os autores ${ }^{20}$ apontaram os seguintes fatores como possíveis responsáveis pelas dificuldades na execução do projeto:

- necessidade de conhecer os projetos realizados na comunidade, para se possível integrar-se a eles;

- trabalhar a questão da interdisciplinaridade, já que a compreensão de mundo implícita nos cursos é bem diferenciada;

- inserir-se nos grupos já organizados, ministrando os cursos dentro das atividades dos grupos.

O resultado desta primeira intervenção criou a necessidade de refletir-se mais sobre as questões culturais e a construção de metodologias que captassem as reais aspirações da população. Mesmo com a baixa participação da população para as atividades educativas, os contatos com a prefeitura,

\footnotetext{
${ }^{20}$ LOPES, Stella Maris B. et all. Programa Universidade Solidária aplicado às comunidades pesqueiras artesanais do litoral centro-norte catarinense. Itajaí:1998. [ Relatório de Projeto de Extensão - ProPPEx. UNIVALI]
} 
associações e a própria população, este trabalho teve como conseqüência a realização de um estágio supervisionado em Fonoaudiologia Preventiva e Educacional no município de Bombinhas.

Neste estágio, procurou-se atender a demanda da prefeitura em relação a cursos para professores e triagem de alunos da pré-escola. Organizaram-se atividades direcionadas aos fatores de risco detectados, desenvolvendo-se programas voltados:

- à caracterização dos bairros a partir do discurso dos habitantes mais antigos de cada bairro, dos presidentes de associação de bairro e profissionais de saúde;

- ao programa de conservação auditiva dirigido aos pescadores artesanais;

- a atividades de educação em saúde para alunos de 1. a a 8. ${ }^{a}$ série;

- ao curso de treinamento a professores, triagem em pré-escolares, atividades de cunho preventivo em sala de aula (pré-escola), atendimento em grupo de crianças portadoras de alterações fonoaudiológicas e grupo de orientação a pais.

As atividades de cunho assistencial contaram com significativa adesão de pais e professores, ocorrendo no decorrer do estágio a contratação de uma fonoaudióloga para o atendimento clínico individual. 
As atividades possibilitaram o conhecimento de todos os bairros do município, reconhecendo-se a estreita ligação dos moradores com o mar e a pesca, e as diferentes formas de lidar com a questão turística no município. No contato com professores, profissionais de saúde e a população, Zimbros começou a diferenciar-se, já que era comum a discriminação dos moradores desse bairro com referencias do tipo: "Ah, prá fazer isso só podia ser lá do Zimbros"; "as mães do Zimbros são assim desleixadas"; "que conhece o nativo daqui, tem de ir lá pró Zimbros, só que eles são muito desconfiados e quietos."

\section{Construindo um estudo.}

Todos estes trabalhos levaram-me a reconhecer que o não-saber sobre a lógica que norteia as ações da população, dificultou tanto o planejamento quanto a execução dos programas propostos, principalmente os ligados à promoção da saúde. Senti a necessidade então de, no mestrado, articular linguagem, família e cultura às possibilidades de intervenção fonoaudiológica em Saúde Pública. 
Busquei neste estudo subsídios teórico-metodológico que auxiliassem a compreensão do universo das representações presentes na cultura em relação ao desenvolvimento da linguagem que permeia a interação de mães e filhos na faixa etária de zero a dois anos, residentes em uma comunidade pesqueira. Para isto, construiu-se uma relação de interpelação ${ }^{21}$ com as Ciências Sociais, suas possibilidades e suas contribuições para a construção do trabalho fonoaudiológico na área da Saúde Pública, especificamente, nas atividades de promoção da saúde voltadas ao contexto familiar que serão abordadas no decorrer do primeiro capítulo.

$\mathrm{Na}$ procura de um método que correspondesse ao objeto, dando conta de conhecê-lo e explorá-lo, optou-se pela abordagem qualitativa. Esta abordagem possibilita a compreensão do sujeito através da linguagem, permitindo um exercício reflexivo de apreensão da realidade ${ }^{22}$ a partir da relação entre sujeitos (pesquisador/pesquisado).

No primeiro capítulo trato da metodologia ao entendê-la como o caminho percorrido pelo pesquisador, visando situar os seus objetivos segundo a teoria que persigo e da realidade como optei pela construção teórica, colocando a linguagem como expressão da cultura e buscando a partir daí a interlocução com a Fonoaudiologia, também faço neste capítulo da metodologia

\footnotetext{
${ }^{21}$ Interpelar quer dizer dirigir a palavra perguntando por uma explicação. ORLANDI, Eni. Interpretação. Petrópolis: Vozes, 1996.

${ }^{22}$ ADORNO, Rubens C.F. e CASTRO, Ana Lúcia. O exercício da sensibilidade: pesquisa qualitativa e a saúde com a qualidade. Revista Saúde e Sociedade.1994; 3(2): 172-185.
} 
este caminho. Portanto, ele não se desenvolve de uma forma linear, mas procura retomar também o modo com que fui percebendo em campo as questões que me interessam neste trabalho.

A pesquisa foi desenvolvida no período de março a junho de 2000, no bairro de Zimbros, em Bombinhas. A técnica de pesquisa utilizada foi a observação participante realizada todas as sextas-feiras na sala de espera da Unidade de Saúde. As mães observadas permaneciam em média de três a quatro horas no posto, vinham acompanhadas de seus filhos para a consulta com o pediatra.

No iicio da pesquisa, o pediatra consultava todas as sextas-feiras, mas a partir de maio as consultas tornaram-se quinzenais. Algumas entrevistas realizaram-se nos períodos em que não havia consulta, a fim de aprofundar-se as percepções da pesquisadora. Nestas explorava-se temas como: vida em Zimbros, criação dos filhos, lugar da mulher, compreensão de como a criança aprende a falar e práticas de saúde.

Todo o material coletado foi registrado em diários de campo e as entrevistas gravadas e transcritas, realizando-se posteriormente a análise do material.

Foram realizadas cinco entrevistas, nas quais li o termo de consentimento esclarecido (em anexo), sendo o aceite gravado. O grupo 
entrevistado foi bem heterogêneo, procurei também observar se as perspectivas das mulheres variavam por serem ou não nativas.

No texto os nomes foram trocados para manter a privacidade das entrevistadas. Conforme elas forem aparecendo no texto serão apresentadas em nota de rodapé. As falas de sala de espera serão identificadas em sua totalidade como textos do diário de campo. Ambos trechos de entrevistas e diário serão destacados do texto e mantidos em itálico.

Os dados organizados são apresentados no decorrer de todo o texto, de acordo com as possibilidades interpretativas vislumbradas na leitura do material. Esta ordenação evidencia mais uma contribuição da pesquisa etnográfica, que por sua característica dialética permite o diálogo entre 0 pesquisador e seus dados por todo o tempo.

No capítulo dois, procuro ao articular linguagem e cultura, explicitar que as mulheres em sua trajetória de vida realizam negociações para a construção de seu lugar como mães, sendo este um processo que passa por escolhas que envolvem a tradição e a modernidade.

No capítulo três, analiso, a partir das práticas das mães e de suas falas, a relação que estabelecem com os filhos e nesta, qual o lugar dado à linguagem. 
O capítulo quatro surgiu do processo da pesquisa, já que durante a mesma fui observando que as mães utilizavam espontaneamente o espaço da sala de espera para legitimar suas práticas e discutir suas dúvidas, além de mostrar como as negociações realizadas pelas mães são dinâmicas e também como as ações dos profissionais podem ou não auxiliar neste processo.

Finalizo, abordando o lugar que a linguagem ocupa nesta comunidade e de que forma a interpelação proposta em direção às Ciências Sociais auxilia na compreensão da dinâmica da comunidade. Evidencio também, o lugar onde a escuta e a interpretação assumem em um trabalho de comunidade e como o fonoaudiólogo pode ser um articulador para que as pessoas valorizem o direito de expressão. 
Imagens das Atividades do Projeto Universidade Solidária Regional em Bombinhas

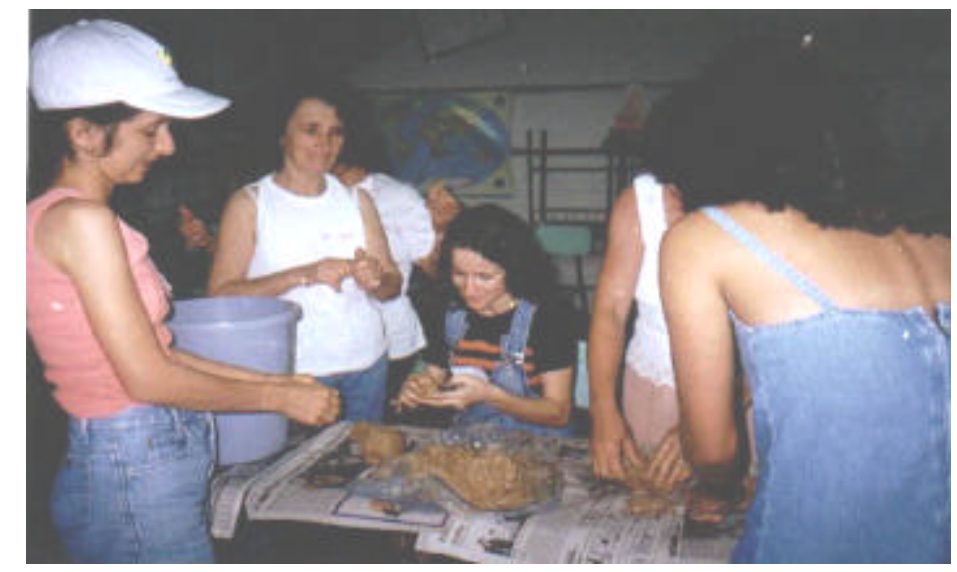

Curso de Saúde da Mulher

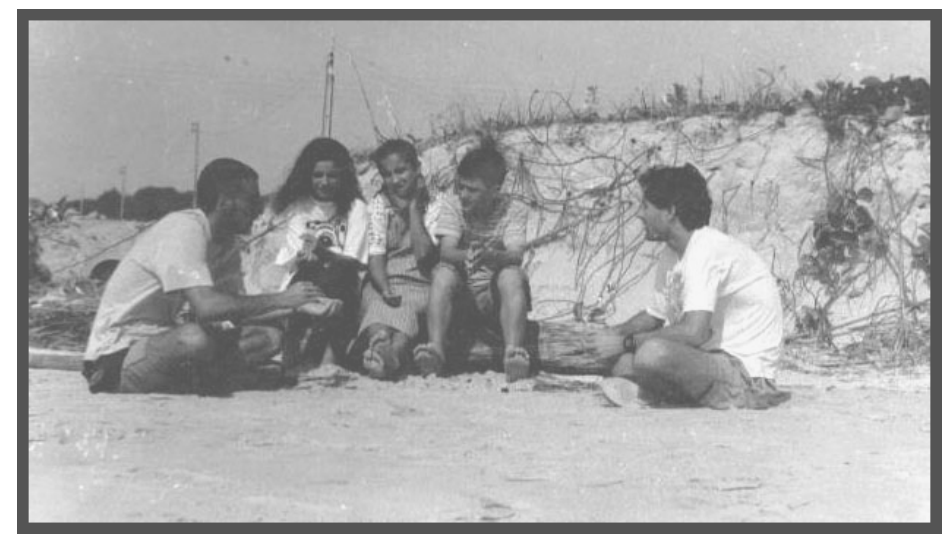

Curso de Educação Ambiental

Sensibilização das crianças para a análise da paisagem 


\section{Atividades realizadas pelo Estágio de Fonoaudiologia Preventiva da UNIVALI no Municipio de Bombinhas.}

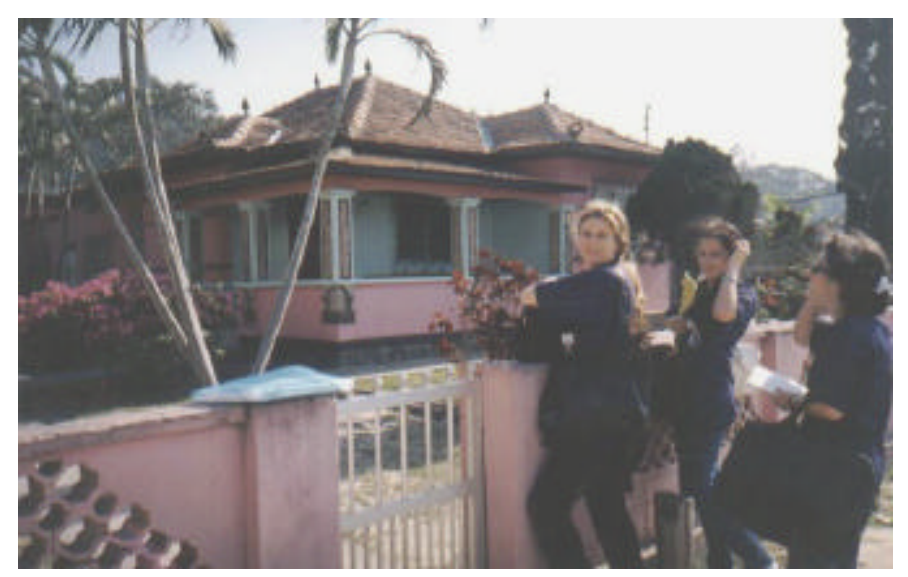

Trabalho nas comunidades com as associações de bairro e as pessoas mais antigas para realização do resgate da história do municipio e levantamento das necessidades atuais.

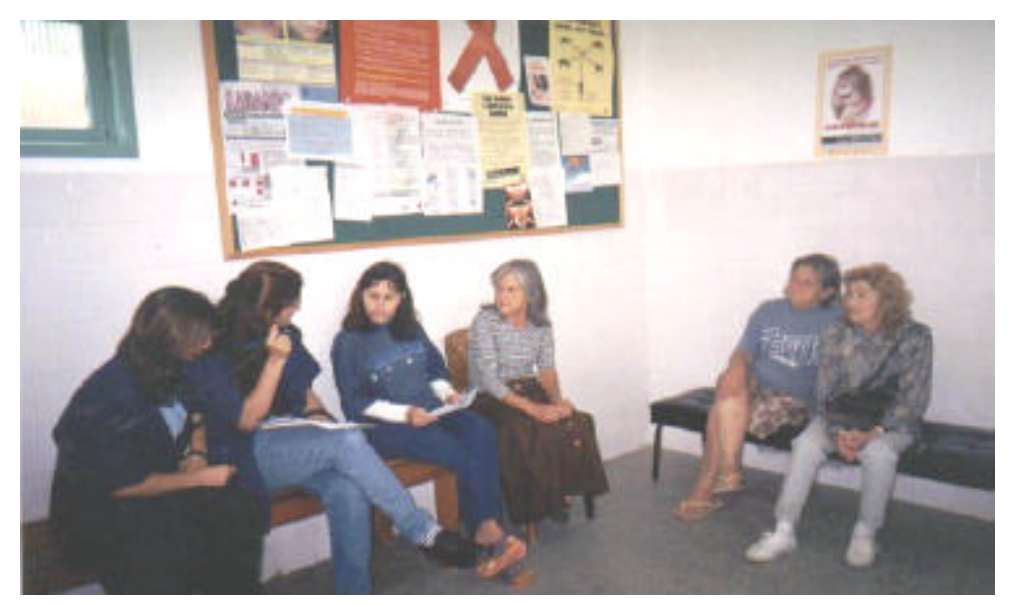

Levantamento do Perfil das queixas auditivas realizado na Unidade de Saúde de Canto Grande. 
Atividades realizadas junto a Secretaria de Educação

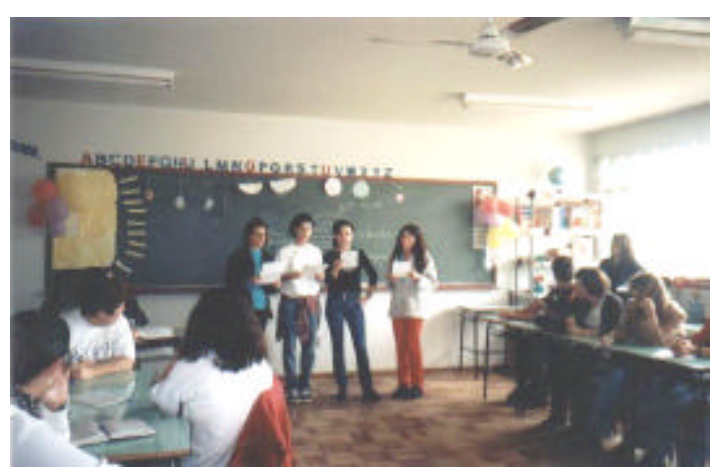

Curso para professores

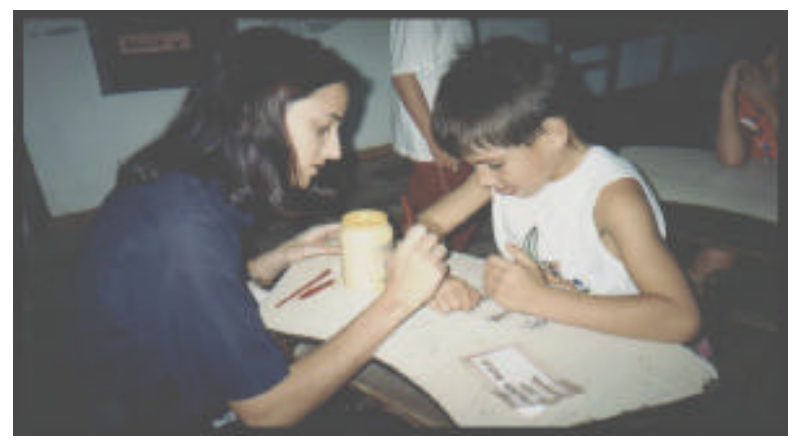

Atividades em sala de aula sobre os temas já trabalhados nos cursos com os professores

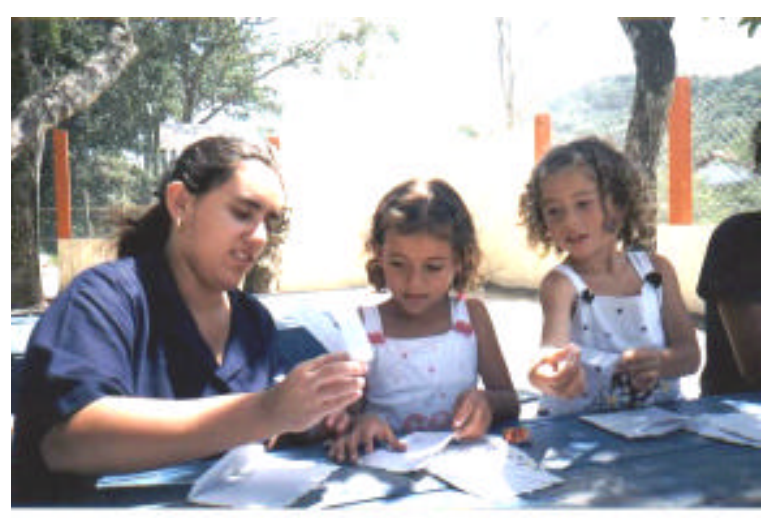

Atividades com grupos de crianças 


\section{Capítulo 1: Caminho Metodológico}

Uma teoria é como uma caixa de ferramentas. Nada tem a ver com o significante. É preciso que sirva, é preciso que funcione. E não para si mesmo. Se não há pessoas para utilizá-la, a começar pelo próprio teórico- que então deixa de ser teórico- é que ela não vale nada ou que o momento ainda não chegou.

Deleuze.

Experiência não é o que acontece com você; mas o que você fez com o que te aconteceu. Aldous Huxley 
Ao procurar desenvolver um trabalho que envolvesse linguagem e cultura não podia restringir-me à escolha e aplicação de uma determinada técnica de pesquisa, tive que num determinado momento elucidar a partir de quais pontos de vista iria trabalhar com a questão.

Como fonoaudióloga já compreendia que o significado de uma expressão ganha sentido na interação com o outro. Caberia construir um caminho teórico-metodológico que permitisse a identificação do papel da cultura na construção dos referidos significados.

A leitura dos trabalhos produzidos na área da Antropologia da Saúde intensificou a necessidade de uma aproximação com as Ciências Sociais, especificamente em relação à sociologia compreensiva que por buscar "compreender e interpretar os significados no contexto objetivo do cotidiano e as definições dos sujeitos sociais em situação, propondo que se preste atenção à maneira como os indivíduos interpretam e explicam a ação social incorporada a vida cotidiana"1 permitiu estabelecer um princípio para a análise dos dados.

Estabelecia assim a primeira marca do trabalho que era a da linguagem não representar os objetos e sim representar a maneira humana

${ }^{1}$ CANESQUI, Ana Maria. Dilemas e desafios das ciências sociais na saúde coletiva. São Paulo:Hucitec-Abrasco,1995.p.14. 
de estar no mundo, resgatando a subjetividade do pesquisador e dos sujeitos pesquisados.

A prática das mães em relação à linguagem dos filhos e a sua dimensão cultural não serão então apreendidas num processo de descrição do contexto, falas e sujeitos como algo externo e possíveis de representarem-se no texto acadêmico por atributos escolhidos e padronizados pelo pesquisador, que caracteriza-os a partir de sua lógica que ele - pesquisador - está apenas replicando, mas a partir do momento em que se consegue estabelecer uma relação e daí, a apreensão de significados. Significados que certamente também são apreendidos e escolhidos pelo pesquisador.

Geertz $^{2}$ ao exemplificar que o significado de um mesmo olhar pode variar da indiferença, exclusão, cumplicidade etc., aponta que a interpretação do olhar vai além do contexto imediato, liga-se a valores existentes no mundo social, podendo se dizer que aí há uma cultura que pede "interpretação".

Se há uma cultura a ser interpretada, toda a coleta de dados deveria buscar traduzir as marcas existentes na mesma e que levam a construção sobre o esperado e o inesperado no desenvolvimento da linguagem das crianças de zero a dois anos. Utilizou-se para isto das

\footnotetext{
${ }^{2}$ GEERTZ, Clifford. A interpretação das Culturas. Rio de Janeiro: LTC,1989. p.13-41.
} 
contribuições da metodologia tradicional da Antropologia, a Etnografia e a observação participante.

Como eram metodologias pouco conhecidas, busquei definições sobre as mesmas, procurando detalhes sobre a maneira que os pesquisadores desta área realizavam suas pesquisas em comunidades.

Utilizei-me da caracterização de etnografia colocada por Geertz $^{3}$ como

uma descrição densa da realidade. Existindo três características para esta descrição etnográfica: ela é interpretativa; o que ela interpreta é o fluxo do discurso social e a interpretação envolvida então consiste em tentar salvar o 'dito' num tal discurso da sua possibilidade de extinguir-se e fixá-lo em formas pesquisáveis.

Há na etnografia uma forte ênfase na exploração da natureza particular de um fenômeno social, investigando um pequeno número de casos através de dados não estruturados. ${ }^{4}$ Assim na coleta de dados utilizam-se técnicas de observação, nas quais o observador, coleta seus dados através de sua participação na vida cotidiana do grupo ou pessoas .

\footnotetext{
${ }^{3}$ GEERTZ, Clifford. Obra já citada.p.31

${ }^{4}$ ATKINSON, Paul e HAMMERSLEY, Martyn. Ethnography and Participant Observation. In: DENZIN, Norman. K. e LINCOLN, Yvonna S. Handbook of qualitative research. London: SAGE,1994. p. 248.
} 
Ele observa as pessoas que está estudando para ver as situações com que se deparam normalmente e como se comportam diante delas. Entabula conversação com alguns ou com todos os participantes desta situação e descobre as interpretações que eles têm sobre os acontecimentos que observou. ${ }^{5}$

Mais que a ação com os filhos, procuro nas falas das mães conhecer o meio pelo qual a vida social é organizada e qual o lugar que a linguagem ocupa nesta organização.

O primeiro momento desta pesquisa, caracterizou-se pela entrada no campo, quando se procurou conhecer as características físicas do local, o uso destes espaços pela população e o contato com a mesma.

A entrada no campo caracterizou-se por caminhadas de reconhecimento do cenário, nelas buscava envolver-me com o ambiente, identificando o padrão e a norma existentes. Neste momento observei os espaços usados pelas mulheres (praia, casa, posto de saúde, rua) e identifiquei as disposições diferentes na construção das casas, explicitando a influência do turismo e também a divisão dos espaços público/privado e dos de dentro e os de fora.

Após estas identificações procurei delimitar um espaço para a observação das mães e seus filhos. Como havia sentido de maneira forte 0

5 BECKER, Howard S. Métodos de Pesquisa em Ciências Sociais. São Paulo: Hucitec, 1993. p.47 
lugar designado à pesquisadora, como estrangeira, optei por realizar as observações em um espaço público e bastante freqüentado por mães de crianças de zero a dois anos. A sala de espera do Posto de Saúde era um espaço utilizado por mulheres de diferentes idades e originárias de vários locais, podendo-se neste contexto utilizar o termo pedaço ${ }^{6}$ já que nela compartilhavam-se notícias dos habitantes da cidade e práticas em relação às crianças e histórias familiares.

Ali encontrava-se o maior desafio, saberia eu o que e como observar? Onde estas observações levariam? Novamente busquei autores que me contassem o que é este processo de observação, identifiquei-me com as colocações de Sarti sobre o desenvolvimento da observação.

Observar não é apenas olhar, mas treinar este olhar preparar cuidadosamente este olhar, para que ele não seja um olhar ingênuo, desarmado, que desconhece suas implicações.

A observação requer que se discuta a concepção da realidade social e conhecimento desta realidade nos quais se baseia, examinando

\footnotetext{
${ }^{6}$ Pedaço: termo que designa espaço intermediário entre o privado (a casa ) e o público, onde se desenvolve uma sociabilidade básica, mais ampla que a fundada nos laços familiares, porém mais densa, significativa e estável que as relações formais e individualizadas impostas pela sociedade. MAGNANI, José Gulherme. Quando o Campo é cidade: fazendo antropologia na Metrópole. São Paulo: Edusp-Fapesp, 1996. p.32.
} 
criteriosamente duas questões do trabalho de campo: como se olha? o que se vê? ${ }^{7}$

A observação poderia ser descrita como um mergulho no mundo das mães e também no meu, trabalho não isento de riscos já que o entendimento da trama construída não pode num primeiro momento ser realizada através de um dispositivo teórico. É este movimento que possibilita a 'relativização' do lugar de cada um, que passa a ser visto de diferentes pontos de vista, rompendo-se com qualquer noção de verdade absoluta. É como se tivéssemos que permanentemente desconfiar de nós mesmos. Busca-se, assim, o exercício (que se reconhece como nunca inteiramente bem sucedido) de não se escandalizar, nem julgar a fala e o lugar do outro. Já que "nenhum costume é inteiramente indefensável, inferior ou bastardo para quem o segue."8

Todo este movimento foi registrado nos diários de campo, no qual anotava o que via, ouvia e as impressões, como dados fundamentais para a análise posterior.

7 SARTI, Cythia. Porque usar técnicas etnográficas no mapeamento. Mimeo-não publicado,1998. p.4-5 


\title{
Do discurso ao campo: as contradições do pesquisador
}

\begin{abstract}
A Unidade de Saúde além de ser o espaço privilegiado de observação, foi principalmente um espaço de reflexão, no qual ficou evidente que apesar do discurso teórico em alguns momentos, não estava preparada para realizar o jogo de espelhos proposto pelo trabalho etnográfico.
\end{abstract}

A construção do trabalho de campo após o reconhecimento do local pode ser divida em dois momentos. No primeiro que se caracteriza pela apropriação através da vivência e da interpretação da mesma, dos movimentos que envolvem este tipo de pesquisa: a alteridade e o estranhamento. E o segundo, o de colocar-se no lugar do outro, que só se torna possível na medida em que nos estranhamos em relação ao que somos, transformando o que aparece como natural em cultural. No trabalho de campo todo este processo ficou claro, como demonstra o texto transcrito abaixo.

"Percebi que como profissional necessitava desenvolver uma escuta em relação à população, já que habitualmente ao trabalharmos em sala de espera sempre ocupamos uma postura de provedor de informações, no qual o espaço cabivel à população era o de questionar e principalmente o de ouvir as informações que tínhamos necessidade de passar.

Fiquei extremamente constrangida pelo fato das mães, durante várias semanas, não perguntarem quem eu era ou o que fazia ali todas as sextas-feiras

\footnotetext{
${ }^{8}$ SARTI, Cythia. Obra já citada. p.5
} 
durante o horário em que o pediatra trabalhava. Uma frase recorrente dos diários de campo era 'hoje novamente ninguém perguntou quem eu era ou o que fazia ali' .

Neste momento pode-se destacar a importância dos registros no diário de campo, pois nele ficaram registradas minhas impressões, a fala das mães, a característica do local, a dinâmica da sala de espera. A análise destes escritos gerou um processo de quietude em relação à obtenção de respostas ou do reconhecimento das mães, valorizando a questão da escuta.

Este espaço então começou a fascinar-me, tive que aprender a escutálas e fiquei, às vezes, chocada, surpresa, sensibilizada, revoltada, mas sempre com questões. A principal delas foi a de questionar a onipotência do profissional, já que as mães resolviam a maioria de seus problemas com soluções construídas em conjunto e para cada um de seus filhos de acordo com os padrões da comunidade, e sabiam claramente o que queriam do profissional e como queriam.

Surgiu o outro lado da fascinação, comecei a ficar muito angustiada, pois, ao questionar minha postura profissional, passei a ocupar um lugar de nãosaber, do não-controle, já difícil de assumir no âmbito clínico. Este processo levoume finalmente ao espaço discursivo, de interpelação e apreensão de significados de que tanto falei, cria-se então uma nova etapa na pesquisa onde os sentidos são dados no momento da interação.

Com o desenvolvimento da observação, a minha inserção na sala de espera modificou-se, o exemplo mais significativo foi o de uma funcionária antiga que sempre que chegava no posto não me encarava ou dirigia sua fala a mim. $\mathrm{Na}$ medida em que foi percebendo o meu não-julgamento, o interesse em estar com as mães $e$ conhecer seu modo de vida, foi gradativamente aproximando-se $e$ estabelecendo uma relação afetiva comigo.

Minha inserção no posto foi marcada pelo termo nega, que manifesta intimidade e inclusão, já que percebia que associado a este termo vieram convites e principalmente discussões sobre conceitos e diferenças entre o meu modo de vida e 
o delas, instalando-se um diálogo bastante reflexivo. Este processo permitia-me conhecer mais das marcas culturais na história das mães daquela comunidade."

O texto acima escrito após uma das análises do diário de campo explicita todo o processo de construção da pesquisa, no qual a ênfase era dada no estabelecimento de contato com as mães e profissionais que frequentavam a sala de espera.

As observações e registros do diário de campo foram relidos e novas observações e interpretações registradas. Por fim, este material foi organizado em texto, a partir dos temas e questões construídas no processo interpretativo realizado durante o campo e na constituição do próprio texto.

O texto produzido ao longo deste trabalho pode causar um certo estranhamento ao leitor, já que em cada capítulo há uma parte introdutória que objetiva mostrar os aspectos conceituais que nortearam as análises. Fujo um pouco da lógica dos textos etnográficos que utilizam jogos de oposição nas categorias e não há uma parte teórica fora da análise, pois nestes estudos a teoria não serve para a validação dos dados e sim para auxiliar na compreensão da estrutura conceitual de uma interpretação, por isto a parte teórica estaria sempre junto ao material a ser interpretado. ${ }^{9}$

\footnotetext{
${ }^{9}$ GEERTZ, Clifford. Obra já citada.p.34
} 
O texto também não se caracteriza pelo desenho habitual dos textos científicos, por não seguir uma estrutura que coloca separadamente resultados e discussão.

O texto expressa o "caminho do pensamento", ${ }^{10}$ já que 0 mesmo é resultante de um processo social, por expressar um saber compartilhado no decorrer da pesquisa. Resgato assim que este é um trabalho interpretativo, não objetiva estabelecer verdades, mas como afirma Geertz, ${ }^{11}$ colocar à disposição "as respostas que outros deram e assim incluí-las no registro de consultas sobre o que o homem falou."

${ }^{10}$ MINAYO, Maria Cecília . O Desafio do Conhecimento. $5^{\mathrm{a} e d}$. Rio de Janeiro: Hucitec Abrasco,1998. A autora cita este termo vinculado por Habermas, ao referir-se a uma análise que tem um enfoque hermenêutico - dialético.

${ }^{11}$ GEERTZ,Clifford. Obra já citada.p.41. 
O espaço da Praia em Zimbros.

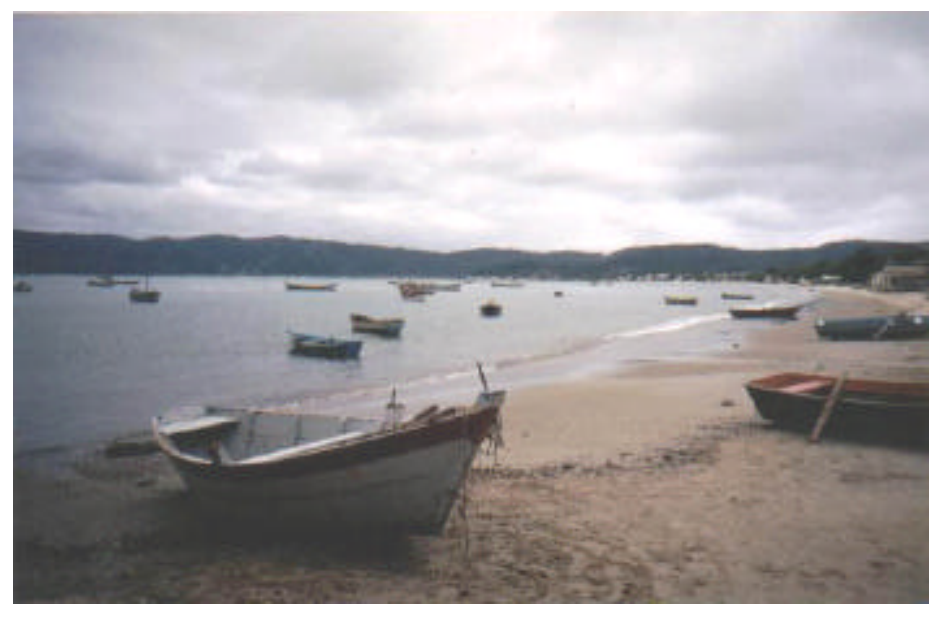




\section{Capítulo 2. Linguagem e Cultura}

De uma cidade, não aproveitamos as suas sete ou setenta e sete maravilhas, mas a resposta que dá às nossas perguntas... ou as perguntas que nós colocamos para nos obrigar a responder.

Ítalo Calvino. 
A inserção da fonoaudiologia nos serviços públicos de saúde tem sido cercada de dificuldades de caráter técnico, político, social e cultural, evidenciando a necessidade da Fonoaudiologia se discutir enquanto uma prática social.

Responder a esta questão exige que a Fonoaudiologia reflita "para quê e para quem realiza seu trabalho, afastando-se de uma visão reducionista do especialista em distúrbios da comunicação." "A ausência de discussões na própria área e também o desconhecimento das políticas de saúde origina algumas práticas equivocadas, como por exemplo: profissionais que escolhem a patologia e a faixa etária dos pacientes que serão atendidos; serviços que realizam apenas triagens e atendimento individual, tendo dificuldade em eliminar as listas de espera; E atendimentos só voltados a escolares entre outros. $^{2}$

Neste contexto inexiste uma relação entre a figura social de quem presta o serviço e a do paciente que o recebe. Se pensarmos que a atuação na Atenção Primária à Saúde busca a construção de ações que envolvam a

\footnotetext{
${ }^{1}$ MAIA, Suzana M. Repensando a Fonoaudiologia. Revista Distúrbios da Comunicação. 1987; $2: 163$.

${ }^{2}$ MENDES, Vera Lúcia F. Fonoaudiologia nas Unidades Básicas de Saúde: a relação com os usuários. São Paulo:1994. [ Dissertação de Mestrado - Pontifícia Universidade Católica de São Paulo]. p.24-86.
} 
participação da comunidade nos serviços e que nesta perspectiva "há necessidade de se estar enfronhado na vivência comunitária e baseado em um requisito da intersubjetividade que é a origem e resultado de todo o processo."3 Percebi que os fonoaudiólogos ao pautarem suas intervenções em questões técnicas ou pessoais acabam encontrando dificuldade em construir uma prática que busque "o reconhecimento e o envolvimento com as questões sociais e com os usuários desses serviços."

Constrói-se assim uma prática muitas vezes ingênua que acaba por descaracterizar a própria linguagem, já que não considera o caráter cultural envolvido no uso, aquisição e construção da linguagem.

Silva $^{5}$ ao estudar a origem das práticas fonoaudiológicas aponta que o afastamento das dimensões culturais e políticas institui um duplo reducionismo:

1) da negação das relações de dominação processadas na e pela linguagem;

2) da falta de compromisso com a interpretação crítica das complexas tramas sociais, envolvidas com a linguagem e suas diversidades, que perpetuam e produzem a dominação e a disciplinarização sociais.

\footnotetext{
${ }^{3}$ LEWIS, Dóris R. Obra já citada.p.139

${ }^{4}$ Idem, idem. p.140.
} 
A autora coloca que mesmo uma compreensão da linguagem voltada apenas aos seus aspectos orgânicos e individuais é decorrente de um contexto histórico que busca o estabelecimento e vinculação de critérios para os ditos "normais e patológicos."

Em relação ao estabelecimento destes critérios, é Cunha que, ao trabalhar com a questão do normal e patológico em distúrbios da comunicação, conta-nos que o estabelecimento da norma só é dado a partir de uma referência e que esta é dada pela cultura. É interessante notar que no percurso do seu trabalho ela contrapõe o discurso científico e depoimentos pessoais, terminando por salientar a importância de valorizar-se o humano.

Acredito que a Fonoaudiologia possa ter uma identidade de ciência humana, dependendo do tratamento que Ihe for dado. Este tratamento deve levar em conta a dimensão de recuperar o objeto que, freqüentemente, perde de vista, fascinado pelo aparato técnico e/ou buscando ampliá-lo. Este objeto é o indivíduo social, no caso (e inclusive patológico. ${ }^{6}$

E é na busca deste indivíduo social que podemos articular linguagem e cultura, tendo como pressuposto que é a linguagem que marca as

\footnotetext{
${ }^{5}$ Silva, Ana Paula B.V. Linguagem e cultura: a construção da norma culta no Brasil, 19201940.São Paulo:1999. [ Tese de Doutorado em História - Pontifícia Universidade Católica de São Paulo]. p. 2-26.

${ }^{6}$ CUNHA, Maria Claúdia. Obra já citada.p.153.
} 
coordenadas da vida em sociedade e enche esta vida de objetos dotados de significação.

Faustino ${ }^{7}$ coloca que o significado de uma expressão qualquer da linguagem ordinária passa a depender de um contexto de uso que envolve um conjunto de atividades e habilidades - lingüísticas e não lingüísticas - que se entrelaçam. $O$ uso da linguagem requer o domínio de uma prática que, no entanto só ganha sentido no contexto de uma forma de vida intersubjetivamente partilhada.

Segundo a autora, descrever as estruturas da linguagem é atingir os "acordos sobre a forma de vida", isto é, os acordos que estão na origem das regras que homens, mulheres e crianças instituem ou convencionam entre si como padrões de uso correto das expressões. É nesse sentido que as explicações do significado adquirem o estatuto normativo de descrições de usos corretos ou possíveis das expressões, e assim a linguagem ganha um caráter

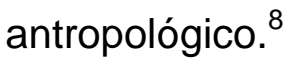

É através da linguagem expressa no/pelo senso comum que a vida social é organizada como significativa. Berger e Luckmann reforçam esta questão pontuando que

\footnotetext{
${ }^{7}$ FAUSTINO, Silvia. Obra já citada.p.94

8 "A Antropologia sempre teve um sentido muito aguçado de que aquilo que se vê depende do lugar em que for visto, e das outras coisas que foram vistas ao mesmo tempo. Para um etnógrafo, remexendo na maquinaria de idéias passadas, as formas de saber são sempre e inevitavelmente locais, inseparáveis de seus instrumentos e de seus invólucros" GEERTZ, Clifford. O saber local. $2^{a}$ ed. Petrópolis, Rio de Janeiro: Vozes, 1999. p.11.
} 
a apreensão do mundo como realidade social dotada de sentido, não resulta de criações autônomas de significado por indivíduos isolados, mas começa com o fato do indivíduo 'assumir' o mundo no qual os outros já vivem. Sem dúvida este assumir em si mesmo constitui em certo sentido um processo original para cada organismo humano, e o mundo, uma vez 'assumido', pode ser modificado de maneira criadora ou (menos provavelmente) até recriado. ${ }^{9}$

Os autores ainda salientam que "a biografia subjetiva não é completamente social, já que o indivíduo apreende-se a si próprio como um ser ao mesmo tempo interior e exterior à sociedade."10

Neste capítulo procurar-se-á conhecer o contexto no qual estão inseridas as mães que participaram da pesquisa, já que ao criar seus filhos estas estarão ressignificando aspectos de sua cultura, tanto para si como para a criança.

\section{Zimbros : espaço de continuidade e descontinuidade}

\footnotetext{
9 BERGER, Peter L. e LUCKMANN, Thomas. A construção social da realidade. 17ª̣ed. Petropolis:Vozes,1999.p.174.

${ }^{10}$ Idem. Idem.p. 180.
} 
Conhecer Zimbros significa conhecer um lugar em transição que mudou muito nos últimos trinta anos e que vive atualmente uma tensão entre a tradição e a modernidade. É uma comunidade que, como outras comunidades pesqueiras, se encontra numa "fase de rompimento com muitas das suas ideologias mais tradicionais ao mesmo tempo em que se transforma grande parte da prática de sua população."11

O conhecer vai passar então pela escuta das relações espaçotempo e da interpretação dos seus moradores sobre estas mudanças. É neste momento que fica mais clara as contribuições da etnografia, já que "o que se vê no campo da observação precisa ser olhado e interpretado a partir do lugar que os indivíduos ocupam no seu mundo social."12

Situando-nos geograficamente, Zimbros é um bairro do município de Bombinhas e que fica em uma península, a qual foi colonizada por açorianos. Inicialmente a população tinha como atividade principal a agricultura, complementada pela pesca.

Devido à maior facilidade de comercialização, a atividade pesqueira fortifica-se, declinando a agricultura. Conforme Mendonça, ${ }^{13}$ os colonizadores açorianos não eram agricultores em sua terra natal, mas devido

\footnotetext{
${ }^{11}$ QUEIROZ, Marcos S. Representação de doença e instituições de cura numa aldeia de pescadores. Campinas:1978. [Dissertação de Mestrado - Instituto de Filosofia e Ciências Humanas da Universidade Estadual de Campinas] . p. 16.

${ }^{12}$ SARTI, Cintia. Obra já citada. p. 5 .
} 
ao sistema de colonização assumiram esta atividade, na qual tiveram muita dificuldade devido às características do solo e a sua falta de conhecimento sobre as técnicas de plantio. Ainda segundo Mendonça, a comunidade de Zimbros viveu isolada por várias gerações, mantendo contato com outras comunidades apenas pelo mar. Até 1970 a água era captada em fontes, só sendo canalizada a partir de 1975. A rede elétrica foi instalada em 1977, chegando a energia elétrica em 1982. O transporte até Porto Belo era feito a pé ou de barco, a primeira estrada feita de areia batida foi construída em 1950 e o transporte coletivo foi implantado em 1973, só que até hoje em dias de muita chuva, o ônibus não circula.

O referido isolamento propiciou um grande número de casamentos consangüíneos, sendo este um fator limitador do crescimento populacional, por levar a grande incidência de deficiências físicas e/ou mentais congênitas, além de freqüentes histórias de natimortos. Estas intercorrências devem-se a dois fatores: no conceito popular não havia casamentos consangüíneos, quando existiam limitavam-se ao casamento de pai e filha, mãe e filho, ou irmãos; outro fator, é a falta de assistência médica já que devido a problemas de transporte, a maioria da população fazia uso da medicina caseira.

\footnotetext{
${ }^{13}$ MENDONÇA, Magaly. Evolução da ocupação da península de Zimbros. Florianópolis: 1984. [ Monografia do Departamento de Geociências - Universidade Federal de Santa Catarina].
} 
Medeiros $^{14}$ chama atenção para a problemática do pescador artesanal que está passando por um processo de exclusão social devido à pressão gerada pelo turismo, especulação imobiliária e pesca industrial.

Os pescadores de Zimbros explicitam neste trabalho a tensão existente entre o pescador e o turista. Apresentam como o principal problema trazido pelo turismo o número excessivo de mergulhadores que segundo eles tem causado o declínio dos cardumes e o aumento do volume de lixo.

Medeiros ${ }^{15}$ conclui que o turismo tem dispersado as comunidades de pescadores, em especial nas comunidades de Bombinhas e Quatro Ilhas, descaracterizando estes locais como comunidades, já que a economia gira muito mais em torno do turismo do que das atividades de pesca artesanal. Esta influência do turismo é menor em Zimbros do que nos outros bairros, conforme os moradores de outros bairros.

(......) cada bairro possui uma característica própria, com jeito de falar e dinâmica própria. Um dia saí de Bombinhas que estava lotado e cheguei em Zimbros, estava uma tranqüilidade. Só quem vai para lá é quem conhece bem o município e pessoas daqui (Blumenau, Floripa, etc. ) que construíram casas lá. (Diário de Campo)

\footnotetext{
${ }^{14}$ MEDEIROS, Rodrigo P. Caracterização sócio-econômica e cultural das comunidades pesqueiras do litoral centro-norte catarinense. Itajaí: 1995. [Relatório Final de Bolsa de Iniciação Científica - Universidade do Vale do Itajaí]

${ }^{15}$ Idem. Idem. p.47.
} 
O lugar e seus habitantes revelam-se aos poucos, andar pela comunidade fornece algumas pistas, mas nada muito óbvio e que não precise submeter-se a interpretações.

No início de Zimbros, vêem-se ruas não pavimentadas, casas não muito agrupadas, existe a escola do estado que tem $1^{\circ}$ e $2^{\circ}$ graus e é bem grande, tem ginásio de esportes do lado e na mesma região há a associação dos pescadores, posto de gasolina e farmácia.

Ao andar pelo bairro identifiquei algumas marcas, como por exemplo sua divisão é dada pelos rios e morro, próximo ao morro residem os nativos e próximo ao rio existem lotes mais definidos onde situam-se as residências dos veranistas. Há três espaços de trânsito: duas ruas largas e a da praia, rua principal, em direção ao morro. Nas ruas observei pouco movimento, apenas crianças brincando em poças de chuva ao lado do mercado.

Cabe aqui salientar que a caminhada sistemática não era aleatória e tinha também a função de treinar meu olhar buscando captar além da "materialidade da paisagem (espaços vazios e construídos, disposição das edificações e equipamentos, escalas, volumetria, ruídos, cores e cheiros) a norma, o padrão."16

\footnotetext{
${ }^{16}$ MAGNANI, José Guilherme. Obra já citada .p. 37
} 
"A velocidade provoca, para aquele que avança num veículo, um achatamento da paisagem (...). As cidades tradicionais, ao contrário, eram feitas para serem vistas de perto, por alguém que andava devagar e podia observar os detalhes das coisas". ${ }^{17}$

É este vagar que Zimbros nos coloca, as pessoas nos quintais ou sentadas na frente das casas imprimem outro ritmo a quem chega.

O espaço da praia é um espaço de trabalho, não de lazer, existe apenas três ruas que vão para o mar nas quais pode se chegar de carro. Vêem-se barcos e alguns pescadores trabalhando nos barcos ou nas redes de pesca, maricultores e suas mulheres na limpeza do marisco e poucas pessoas passeando.

É nas vielas que a vida parece pulsar, vê-se grande movimento de crianças nos quintais, mulheres nos seus afazeres domésticos e homens trabalhando em construções ou em atividades de pesca. Ao penetrar neste espaço percebi que algumas pessoas saíam à janela para olhar quem era, pareceu-me que o andar nas vielas é entrar na intimidade deles. Eles olhavam bastante, mas sempre cumprimentavam.

\footnotetext{
${ }^{17}$ PEIXOTO, Nelson apud FLORES, Maria Bernadete R. A farra do boi: palavras, sentidos, ficções. 2. ${ }^{a}$ ed. Florianópolis: Ed. da UFSC, 1998. p..23.
} 
Nas caminhadas observei e vivi situações que me remeteram à separação entre a casa e a rua, colocada por Da Matta ${ }^{18}$, "como o fato das pessoas informarem ao estrangeiro a posição das moradias de modo personalizado e até mesmo íntimo." Como no episódio registrado no diário de campo, transcrito a seguir.

Certo dia estava atrás da merendeira de Morrinhos, e as informações que recebia eram do tipo: ela está na casa do Maneco que mora logo ali do lado do João ou vá lá fica do lado da boutique da Márcia, só que ainda não abriu não tem nem a placa.

A lógica do espaço se confunde com a própria ordem social, em Zimbros a maioria dos nativos mora perto do morro e as casas próximas da escola concentram os estrangeiros.

A primeira vista parece que o espaço da intimidade, das relações é o da casa, mas nos relatos há indícios de que em outros tempos o espaço da rua era um espaço mais relacional. Já que a própria atividade produtiva (pesca) e o comércio local exigiam ações coletivas, como explicita o depoimento abaixo:

Antes era tudo muito junto, os homens iam para o mar pegar o camarão e quando chegavam despejavam na mesa, a gente conversava, ficava se olhando enquanto limpava o camarão... Na época da corvina os

${ }^{18}$ DA MATTA, Roberto. A casa @ a rua. 5ee․ Rio de Janeiro: Rocco,1997.p.30. 
homens iam para o mar, e as mulheres no final do dia iam para a praia esperar eles, seus maridos, pais, primos e irmãos. A gente pegava balaios velhos, enchia de madeira, palha que tinha ali na praia e acendia fogueira e ficava conversando, daqui até Morrinhos você via umas quinze fogueiras na enseada, era lindo de se vê. E quando eles chegavam do mar a gente ajudava a recolher o peixe e o consertava. ${ }^{19}(\text { Ivana })^{20}$

Hoje parece haver três espaços: o da casa, do terreno e da avenida; que seriam respectivamente a intimidade, o espaço das relações próximas (parentes, filhos) e o público. Já que os moradores com melhores condições financeiras constroem ranchos no seu quintal e no verão moram neles, alugando suas casas para os veranistas.

Antigamente as atividades de lazer também eram grupais e envolviam o contato entre as comunidades.

Todo mundo ía para a praia e lá que era o movimento, você via cheio de casais que trilhavam a areia de um lado para o outro, primeiro só se olhando.

\footnotetext{
${ }^{19}$ Consertava ação que implica em tirar as escamas e a cabeça do peixe. Estes depois da salga eram colocados em caixinhas de madeira para exportação.

${ }^{20}$ Ivana ,moradora antiga de Zimbros, trabalha no posto de saúde e cuida dos netos. Ao chegar ao posto foi a pessoa mais arredia ao contato, só a partir do quinto encontro é que voltou sua fala para mim, antes falava comigo sem se dirigir a mim. Desviava-se das perguntas, não olhava nos olhos e às vezes nem me cumprimentava. Após seu aceite, mostrou-se uma pessoa
} 
As meninas brincavam de roda, amarelinha, gato e rato, jogo da vara. Meninas de doze anos tudo inocente. Não se brinca mais como antes. (Ivana)

Flores $^{21}$ afirma que 0 ato de brincar reforça os relacionamentos grupais e o indivíduo, ao colocar-se na brincadeira, mantém e reforça sua identidade. A própria repetição tem um significado essencial na brincadeira: possibilita que o indivíduo se torne senhor de suas experiências e ao retomálas, ele as ressignifica no seu presente, dando-Ihes sempre um novo ímpeto.

Nos domingo a gente ia na praia Vermelha e todo mundo se encontrava lá. A gente ia para praia até porque não tinha luz, então a gente pegava uma malha colocava querosene e andava por aí, e ia para a praia conversar em volta das fogueiras.

Tinha baile também, antes os pais podiam largar para os bailes sem medo. Nos bailes sempre dava briga, principalmente com o pessoal de Canto Grande. Ah, o pessoal daqui não era fácil, eles eram capazes de sair do jogo de futebol para ir brigar. (Ivana)

A festa, pelo seu caráter repetitivo, pela sua particularidade em reunir a coletividade, pelo momento de exacerbação da vida social, pode nos mostrar uma outra organização social. Ademais, pelo fato de grande

muito simpática e disponível, sendo uma das maiores informantes em relação às práticas tradicionais.

${ }^{21}$ FLORES, Maria Bernadete R. Obra já citada.p.152. 
parte das categorias sociais - trabalhadores manuais, mulheres e crianças, minorias étnicas, idosos , etc. - quase nunca produzirem documentos escritos, a festa pode significar o momento em que estas minorias expressam, por meio da palavra ou outras linguagens, seus valores, suas crenças, enfim, sua cultura. A festa pode ser ainda o lugar dos bodes expiatórios, dos conflitos, das exclusões, de controle, da disciplina, da educação e reforma do povo, bem como de resistência a todos estes processos. ${ }^{22}$

Em Zimbros, além dos bailes e jogos de futebol, as festas religiosas eram também outro momento de reunião, nas quais apresentavamse o terno de reis, pau de fita, boi de mamão.

Nesta fase as tradições eram compartilhadas e, segundo as mães era mais fácil de educar os filhos pois as regras eram as mesmas. Segundo Ivana, todo mundo falava a mesma língua, todo mundo se conhecia e as coisas que podiam eram para todos.

Além de estabelecer e unificar as regras da comunidade, era através da língua que marcava-se a continuidade familiar como coloca Mendonça, ${ }^{23}$ pois marca outro aspecto da língua como manifestação cultural, segue descrição do texto.

\footnotetext{
${ }^{22}$ Idem, idem. p.46

${ }^{23}$ MENDONÇA ,Magaly. Obra já citada. p. 78.
} 
(...) As esposas geralmente não usam o nome do marido, nem as filhas o nome do pai. As crianças do sexo feminino recebiam parte do nome e do sobrenome da mãe, o mesmo ocorrendo com as do sexo masculino em relação ao nome do pai. Por exemplo: a mãe de D. Lindomar Florência de Melo, chamava-se Florência Rita de Melo e a avó, Rita Alexandrina de Melo. ....O marido de D. Lindomar (seu Gonza) chamase Manoel Guilherme de Melo, o pai dele chamava-se Guilherme Vicente de Melo e o avô, Vicente de Melo. O pai do Sr. José Alzira de Melo (seu Zé Chico) era Francisco Vicente de Melo (que também era filho de Vicente de Melo, avô de seu Gonza) O Sr. José Alzira de Melo, no entanto recebeu o segundo nome (Alzira) de sua mãe, Alzira Joaquina Faial. Mas, até hoje ele é conhecido na comunidade como "seu Zé Chico", isto é, o José filho do Francisco.

Atualmente os nomes das crianças carregam além da continuidade familiar o desejo de saída ou mudança como indicam o nome em inglês, de cantores evangélicos ou sertanejos, revelando a expectativa das mães frente ao futuro dos seus filhos.

"Quando a mãe da Elloysa soletrou o nome dela, todas as mães comentaram: você não registrou aqui né? Pois aqui eles não deixam nome em inglês; meu marido queria colocar Maicon com y e não deixaram; quem quis esta coisa em inglês?" (Diário) 
Eu não queria que ela tivesse meu nome. Mas ele foi lá e coloco, mas eu não puxo muito por ele.

Havia uma menina que chamava-se Cálita, quando achei o nome diferente as mães comentaram que é o nome de uma cantora de uma dupla evangélica. A mãe da menina comentou: não sei se é bom ter nome diferente, a gente sempre tem que ficar explicando. E a avó comentou: nome igual ao dela não tem aqui no Zimbros, só lá em Blumenau.

Outra mãe comenta que tem um filho Leonardo e outro Leandro e diz está cheio por aí, eu tive quatro filhos depois de três abortos e coloquei todos os nomes deles com a inicial do meu L. para o último não sabia que nome dar então coloquei o nome do pai. (Diário)

E é no contato com o novo que nasce a ruptura com o passado. Mais que isso , "novo" significa um esquecimento, uma ausência de passado, talvez por isso o tempo passado também seja um tempo idealizado, pois os mais velhos percebem a diluição da tradição, do passado, no novo.

A urbanização e as questões da produção ampliam as redes sociais, antes o estranho era o vizinho de Canto Grande, hoje o estranho pode ser da região e até de outro país, isto influencia e aproxima os moradores "nativos". 
Hoje em dia eles são tudo amigo, amigo mesmo. É depois que a pesca diminuiu aqui e eles começaram a pescar embarcados em Santos, São Vicente, Rio Grande eles tiveram que trabalhar juntos aí ficaram mais civilizados, diz Ivana.

$\mathrm{Na}$ medida em que aumenta o contato com outras comunidades e o número de turistas, ocorre a entrada de novas pessoas na comunidade, iniciando-se a separação entre nativos e os de fora.

Sou nativa , nasci aqui. (Simone) $)^{24}$

Nosso lugar já não é o mesmo. Hoje não tem nem vinte por cento de gente daqui nossa, o resto é tudo de fora, tá cheio de paranaense aqui, tudo gente perigosa. Hoje não confio mais em sair de casa e deixar a casa aberta. (Ivana)

Eu conheço praticamente todo mundo aqui, porque a gente mora, cresceu aqui, né. Mas eu que eles vieram para cá porque eles também tão necessitados, né. De serviço, de um lugar bom prá morar, porque aqui é um lugar bom prá morar. Eu gosto. (Janete) ${ }^{25}$

\footnotetext{
${ }^{24}$ Simone, filha de pescador e mãe de um menino de 1 ano, tem 30 anos. Morou fora de Zimbros, no interior de São Paulo, por uns cinco anos. Antes de casar iniciou o curso de Enfermagem, interrompido pela exigência de repouso durante a gestação.

${ }^{25}$ Janete, mãe de dois filhos, nasceu em Zimbros e tem 27 anos. Durante o ano não trabalha sistematicamente, apenas cuida das casas de alguns turistas. Já na temporada trabalha de doméstica nestas casas.
} 
O contato com o diferente, o moderno, o novo, não traz só a perda de valores, mas também revela um movimento inverso, a identificação e afirmação de uma identidade comum a seus moradores, que pode ser traduzida nas frases: sou nativo, sou daqui.

O estranho, em outras palavras, não é apenas alguém que pertence ao 'mundo desconhecido fora daqui', mas uma pessoa que por permanecer, obriga os habitantes locais a tomar uma posição. É preciso estabelecer se o estranho é ou não um 'amigo' - se ele ou ela não vai embora novamente - o que não é o mesmo que aceitar o estranho como alguém da comunidade, um processo que pode levar muitos anos, ou mesmo nunca acontecer. ${ }^{26}$

Percebe-se este processo no município inteiro, marcando o lugar do nativo e do estrangeiro, um exemplo são as associações dos amigos de Bombas e Bombinhas (pessoas de fora que veraneiam ou moram lá) e a associação dos filhos de Bombas (nativos). A enfermeira do posto de saúde de Zimbros relata que sua entrada na comunidade foi via auxiliares de enfermagem, pois estas eram ou nativas ou moravam lá há mais de 20 anos. 


\section{O nativo e o estrangeiro}

Os estrangeiros, além da mudança na ordem econômica, já que muitos pescadores começaram a trabalhar na construção civil e suas mulheres a cuidar das casas, trouxe também novos moradores que tem uma relação tensa com os nativos.

É que eles ainda não se convenceram que eles vivem há mais de 20 anos do turismo, não declarado, mas é turismo. E como eles não têm mais, vamos dizer eles não têm um conhecimento melhor para implementar o turismo deles na região eles têm medo. Eles não querem é claro que passe além daquilo que eles podem oferecer, e que a pesca não tá mais o que era todo mundo sabe disso. (Roberto marido da Kátia $)^{27}$

Ah, com certeza oitenta por cento das pousadas são de gente de fora. (Kátia)

Eles não querem é trabalhar. (Roberto)

${ }^{26}$ GIDDENS, Anthony. As conseqüências da modernidade. São Paulo: Ed. da UNESP, 1991. p.77.

${ }^{27}$ Roberto e Kátia são um casal de Porto Belo, casaram há um ano e meio e tem uma filha. Vieram morar em Zimbros logo que a filha nasceu. Ela se relaciona pouco com as pessoas do lugar e quando vai ao posto, é uma das poucas que leva brinquedos para a filha. 
Há nestas falas uma visão de nativo, a ser entendida, pois os açorianos desde os relatos dos viajantes foram encarados como pessoas de boa índole, mas preguiçosos quando comparados com os germânicos.

Flores $^{28}$ relata que a obra de Othon Dama D’Eça expressa o sentimento presente nas elites da região litorânea. Nas primeiras décadas do século $X X$, era de que a região é estagnada porque seus habitantes são um povo de índole fatalista, simples, arraigado às crenças e superstições, conformado e até satisfeito. Na sua obra, a pobreza é vista como positiva e nobre, na medida em que há amor entre os casais, na alegria e na dor, trabalho diário pelo pão do dia-a-dia, luta constante contra as doenças das crianças, a miséria, a fome e a morte que vem do mar.

Paralelamente, as regiões colonizadas por alemães progrediam economicamente e nas décadas de 30 e 40 há um processo de nacionalização dos municípios, já que se identificava nestas colônias ações de preservação da identidade alemã: na língua, costumes, religião. As ações evidenciam o conflito em torno da oposição entre brasilidade $\mathrm{x}$ germanidade do Estado de Santa Catarina, numa disputa pelo poder hegemônico no Sul do País. Uma hegemonia que não dependia apenas da força e do progresso econômicos, mas principalmente de sua identidade cultural. É neste contexto que Flores aponta a invenção da açorianidade, neste momento não se fala do "homem do litoral", de uma perspectiva pessimista, como homem "indolente e incapaz", mas 
se fala do "açoriano" (o mesmo homem ontológico e biológico) como aquele que historicamente, deu seu sangue, sua vida, sua bravura, sua história, na construção da brasilidade de Santa Catarina. Este momento foi marcado pela realização do $1^{0}$ Congresso de História Catarinense que tinha como tema a colonização açoriana.

Paralelamente, a partir de 1950, o litoral de Santa Catarina começa a ser redescoberto, crescendo o comércio e assim desencadeando uma melhoria do nível de emprego e das condições de vida. O traço açoriano volta a ser revalorizado como objeto do turismo e novamente recria-se a história, mais fortemente em Florianópolis, mas atingindo toda a região litorânea.

Seu povo herdou dos ilhéus açorianos um

caráter humilde e bom, excelentes qualidades morais, de índole trabalhadora, tenacidade e paciência. Seu protótipo é o Manezinho da Ilha, aquele que representa o espírito do lugar; falar meio cantado, uma certa maneira de colocar as opiniões e um certo humor. Para encontrá-lo há que sair pelas ruas . e pegar um cara que nunca se viu e conversar com ele. 'Vai ouvir um português seiscentista, vai tomar conhecimento do fantástico, da mitologia de que está impregnada a região'. O título já

\footnotetext{
${ }^{28}$ FLORES, Maria Bernadete R. Obra já citada.
} 
foi pejorativo; hoje é chique e entre os meios intelectuais, há concurso e festa do 'Manezinho da llha. ${ }^{29}$

Durante o trabalho em Zimbros, também era presente a questão da boa índole e simplicidade dos nativos, como nos exemplos abaixo:

Os daqui são os que consomem e os de fora são os que fazem o tráfico.( Luciana $)^{30}$

É o pessoal acostumou mal, veio para cá tinha dinheiro na época, explorava o pescador, tadinho. (Luciana)

O que tudo isso tem a ver com este trabalho? Com Zimbros? Com mães? Tem a ver com o meu imaginário, ao ler os textos de Flores e Severino, ${ }^{31}$ percebi que ao ir para o campo minha cabeça também estava cheia de imagens do açoriano, do simples e supersticioso. As conseqüências foram a busca constante das superstições sobre a fala, das marcas sobre a diferença e do choque frente à farra do boi, não é à toa que um dos meus diários de campo trabalhava com a questão da minha falta de escuta a certos discursos, momento marcante do trabalho que me fez construir uma nova relação com o posto e seus usuários.

\footnotetext{
${ }^{29}$ Idem. idem. p.140.

${ }^{30}$ Luciana profissional de saúde que trabalha no município há mais de cinco anos, nasceu em Itajaí.
} 


\section{Recriando Identidades na Fala dos Moradores}

Pensar em identidades é pensar em histórias de vida, trajetórias pessoais e em visões de mundo. ${ }^{32}$ Falar de identidade é lidar com a forma como as pessoas se posicionam em relação ao outro, a farra do boi é um dos melhores exemplos das diferentes negociações realizadas entre as pessoas. eles antes vinham de carro de boi, a outra falou besteira eles vinham de barco lá de Santa Luzia, ficava um pouco aqui depois ia para $o$ Canto Grande.

Hoje o boi estaria no mangueirão as quatro, a Fátima falava: ainda bem que hoje vou sair cedo e levar meu mais novo, nem vou ver isso, a Ida falou: eu já saio daqui direto para lá.

Como não é liberado o boi não é solto fica no mangueirão e é toreado.

S: Deve ter ficado mais sem graça.

F: É a graça tava em correr atrás dele pelos morros, tinha boi que ficava três, quatro dias no mato. Quem tem sangue açoriano nas veias é que

${ }^{31}$ SEVERINO, José Roberto. Itajaí e a identidade açoriana: A maquiagem possível. Itajaí: Ed. da Univali, 1999.

${ }^{32}$ RODRIGUES, Núbia e CAROSO, Carlos A. Idéia de 'Sofrimento' e Representação Cultural da Doença na Construção da Pessoa. In: DUARTE, Luiz Fernando D. (org.) Doença, sofrimento, perturbação: perspectivas etnográficas. Rio de Janeiro: FIOCRUZ, 1998.p.138. 
gosta (olhando para Ida e rindo), o meu marido e meu mais velho adoram.

Contaram vários casos na região em que se está discutindo, brigando, estudando a dita farra. (Diário de Campo)

Toda Santa Catarina gosta é uma coisa nossa é a mesma coisa de dizerem para tirar o carnaval do Rio de Janeiro. (Ivana)

O trecho acima remete à polêmica existente em torno da farra do boi, sendo que elas salientam a antigüidade da festa, sua identidade com 0 Estado comparando-a ao samba, com o sangue açoriano e com a ludicidade da festa. A farra recebe significados opostos: tradição; barbárie, festa, crueldade, ignorância, que contrastam com a identidade açoriana construída.

Flores, ao analisar a imagem que a Farra do Boi apresenta, formada pela mídia, instituições governamentais, não governamentais e aparato policial, cria um espaço para a reflexão sobre

o destino das chamadas festas populares em sociedades marcadas pela indústria cultural. Destino inglório, pois a indústria cultural, ao incorporar tais festas, acaba, afinal, pelo seu próprio metabolismo de iconização e repetição infinitas, por destruí-las, esvaziando-as de qualquer sentido. ${ }^{33}$

\footnotetext{
${ }^{33}$ SALIBA, Elias. in Flores, Maria Bernadete R. Obra já citada. p.15
} 
A farra do boi configura-se numa festa tradicional que ocorre em 23 municípios, quase todos na faixa litorânea do Estado de Santa Catarina. Envolve aproximadamente 60 localidades nas áreas urbanas, rural e pesqueira. Realiza-se principalmente na Semana Santa e começa quando grupos da comunidade cotizam-se para comprar um boi brabo. Costumeiramente, depois que o boi corre pelas ruas, investindo e desafiando toda a população, embrenha-se no mato e começa então a sua caçada.

Os farristas enfatizam o caráter lúdico da atividade, sempre se remetem ao fato de brincar com o boi e que enfrentá-lo é um ato de coragem. "É uma festa marcada pelo desgoverno, a ausência de normas e de fronteiras entre o público e o privado, entre noite e dia, entre consumo e economia. A estripulia e a embriaguez dão o clima de sua completa realização"34

S. Mas não judiavam muito do boi?

Que, que era um monte de bêbado correndo atrás do boi $O$ boi é que fazia eles de tolo.

É não tinha nada de judiaria não, eles não entendem que é coisa nossa.

S.E onde fazem?

Ali no mangueirão perto do posto, uma vez soltaram o boi ele deu uта volta e foi pro mar, aí os homens afogaram ele.

S. Ah e isso não é judiar?

Judia nada, é a nossa tradição. (Diário de Campo )

\footnotetext{
${ }^{34}$ Idem. Idem.p. 166.
} 
A farra mostra uma sensibilidade diferente aos animais, contrastando com a imagem que se tem do homem do litoral catarinense como bom, dócil, paciente e resignado. Flores ${ }^{35}$ exemplifica o contraponto desta imagem dos catarinenses ao citar o texto "O tumor catarinense" no qual o autor aponta: "bois e vacas de olhos furados, ossos quebrados, castrados e esfolados lentamente. Não existe no resto do mundo nada parecido com o que acontece no litoral de Santa Catarina (...) Este ano o País começou a sentir o cheiro de podridão daquela terra tão linda."

Este é um dos exemplos de um movimento nacional e internacional contra a farra, cuja repercussão manifestou-se em campanhas publicitárias, educacionais, organização de Comissões para o estudo da festa, chegando à repressão policial aos farristas.

A população resiste à proibição, afirmando reinteradamente a identidade açoriana da festa. Em vários pontos do litoral há choques entre a população e a polícia, principalmente no município de Governador Celso Ramos. A comissão encarregada de propor medidas contra a farra do boi, percebe que esta não poderia ser extinta, então, decide encará-la como um costume a ser normatizado, surgindo o mangueirão.

Procura-se deste modo a homogeneização da farra do boi, Flores relata que os municípios nos quais o turismo era uma importante fonte de

\footnotetext{
${ }^{35}$ Idem.Idem. p.89.
} 
renda, como Bombinhas, havia uma maior concordância na direção da organização e disciplinarização.

Como não é liberado, o boi não é solto. fica no mangueirão e é toreado.

$S:$ Deve ter ficado mais sem graça.

É a graça tava em correr atrás dele pelos morros, tinha boi que ficava três, quatro dias no mato. Quem tem sangue açoriano nas veias é que gosta (olhando para I e rindo) o meu marido e meu mais velho adoram(Diário)

A população de Zimbros "adapta-se " às normas, abrindo mão da graça de brincar com o boi pelos morros, duas vezes pude ver o alvoroço das pessoas do município (todos os bairros, não só Zimbros), para participar desta festa sem hora, que reunia pessoas de todas as idades e classes.

As crianças ressignificam a tradição.

O menino disse que agora que não pode mais fazer com o boi, um menino se faz de boi entra no mato e os outros correm atrás. Afinal a gente tem de manter a nossa tradição, fala a mãe do menino de dois anos. (Diário)

Relato semelhante foi realizado por um menino de Ganchos, sobre o qual Flores ${ }^{36}$ explora o sentido que a farra tinha para as crianças, "a criança partilha a festa com os adultos desde muito pequena, porque a festa do boi tem 
seu caráter carnavalesco. Não é para ser vista de fora, não constitui um lugar onde se representam papéis. Ela é vivida, sentida, experimentada. Não há ritual de iniciação, não há separação de idade ou sexo. O clima de festa, dado pelo corre-corre, pelo risco, pela visão misteriosa do boi, pelas ruas agitadas, é para todos, inclusive para os pequenos. Os caminhos, vielas, quebradas, subidas e descidas do espaço desorganizado da cidade formariam um labirinto para o estranho que ali chegasse. Mas não para a criança que ali cresceu e conhece cada esconderijo, cada moita de bambu, cada trilha, cada barraca. Ela conhece seu pedaço no que ele tem de topográfico, de cores, de cheiro, de movimento, de vida. E o que é significativo em sua cultura aparece ressignificado e experimentado em suas brincadeiras."

Giddens $^{37}$ afirma que "seja pessoal ou coletiva, a identidade pressupõe significado, mas também pressupõe o processo constante de recapitulação e reinterpretação observado anteriormente. A identidade é a criação da constância através do tempo, a verdadeira união do passado com um futuro antecipado. Em todas as sociedades, a manutenção da identidade pessoal e sua conexão com identidades sociais mais amplas é um requisito primordial de segurança ontológica."

Acredito que todas as características de Zimbros traçadas neste capítulo, exemplificam que as implicações sociais do trabalho fonoaudiológico

\footnotetext{
${ }^{36}$ Idem. Idem. p.95.

${ }^{37}$ GIDDENS, Anthony. Obra já citada. p.100.
} 
para existirem, envolvem o conhecimento das representações do cotidiano no qual estabelecem-se os jogos de linguagem. ${ }^{38}$ Isto é, os múltiplos acordos que levam a integração e desintegração social dos seres humanos.

${ }^{38}$ Linguagem tida como um fenômeno público ou social enraizado nas formas de vida: a autocompreensão do indivíduo pode ocorrer apenas nos termos dos conceitos publicamente disponíveis. WITTGENSTEIN, Ludiwig. Investigações Filosóficas. Trad. José Carlos Bruni. São Paulo: Nova Cultural,1996.p.294 


\section{As ruas de Zimbros}

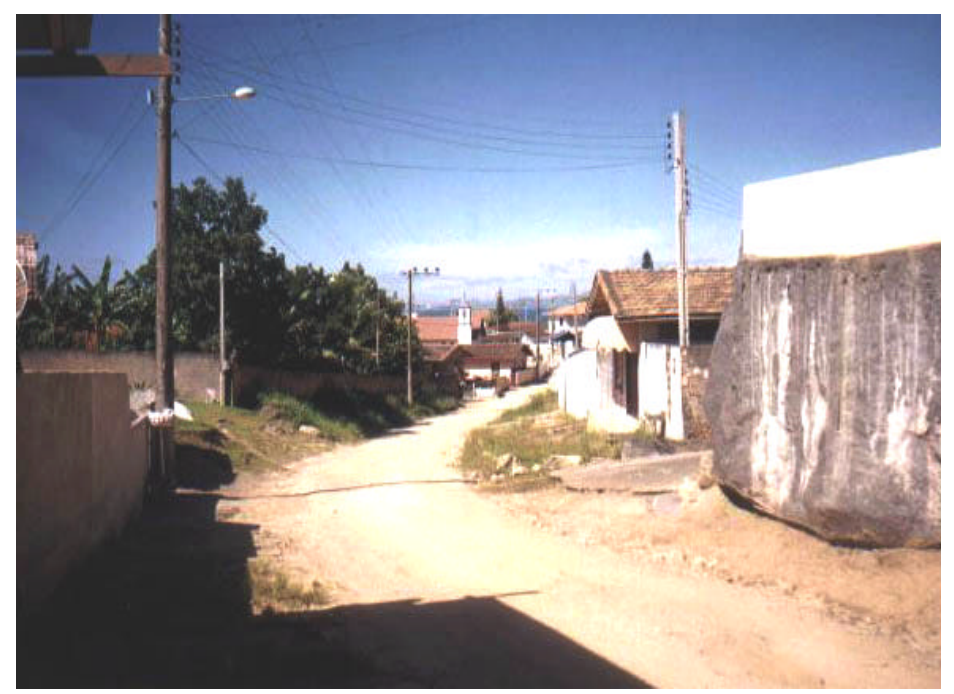

Região que concentra moradores mais antigos, próxima ao morro, calçada apenas na região da praia. É uma das poucas ruas em que se pode chegar de carro próximo ao mar. 


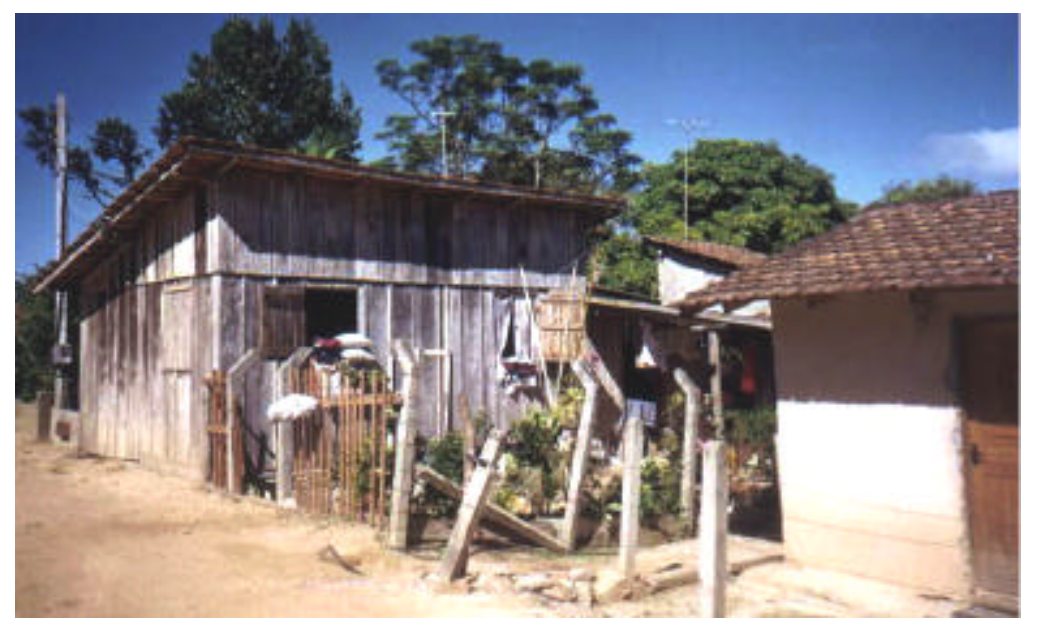

Maioria das casas é de alvenaria ou mistas, em pontos mais afastados encontram-se várias casas de madeira.

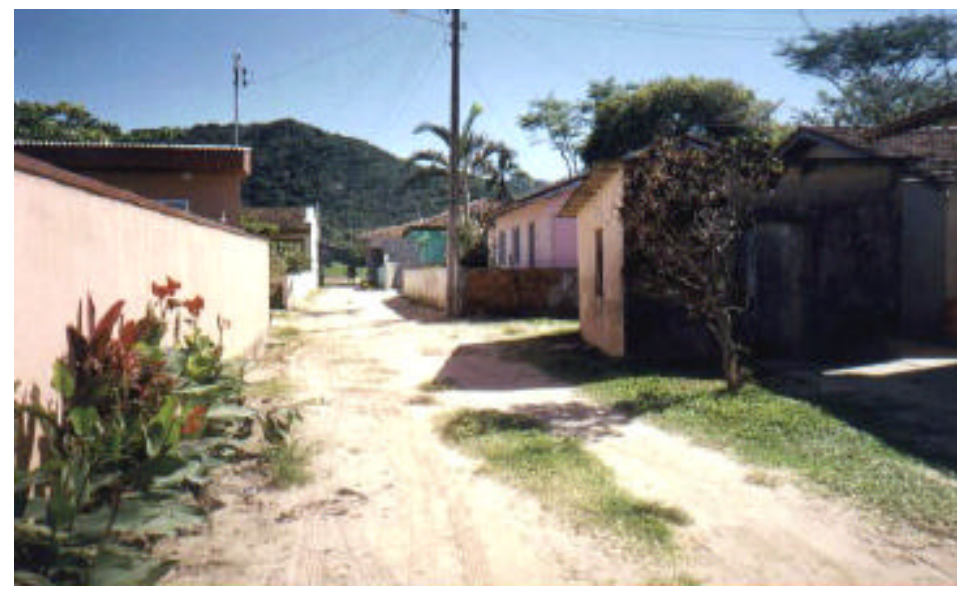

Uma das inúmeras vielas, nas quais normalmente há duas ou três casas por terreno. 


\section{Festas tradicionais da Cultura Açoriana}

Terno de Reis. Foto de Catarina Rudiger, 1998.

Florianópolis, Ilha Açoriana.
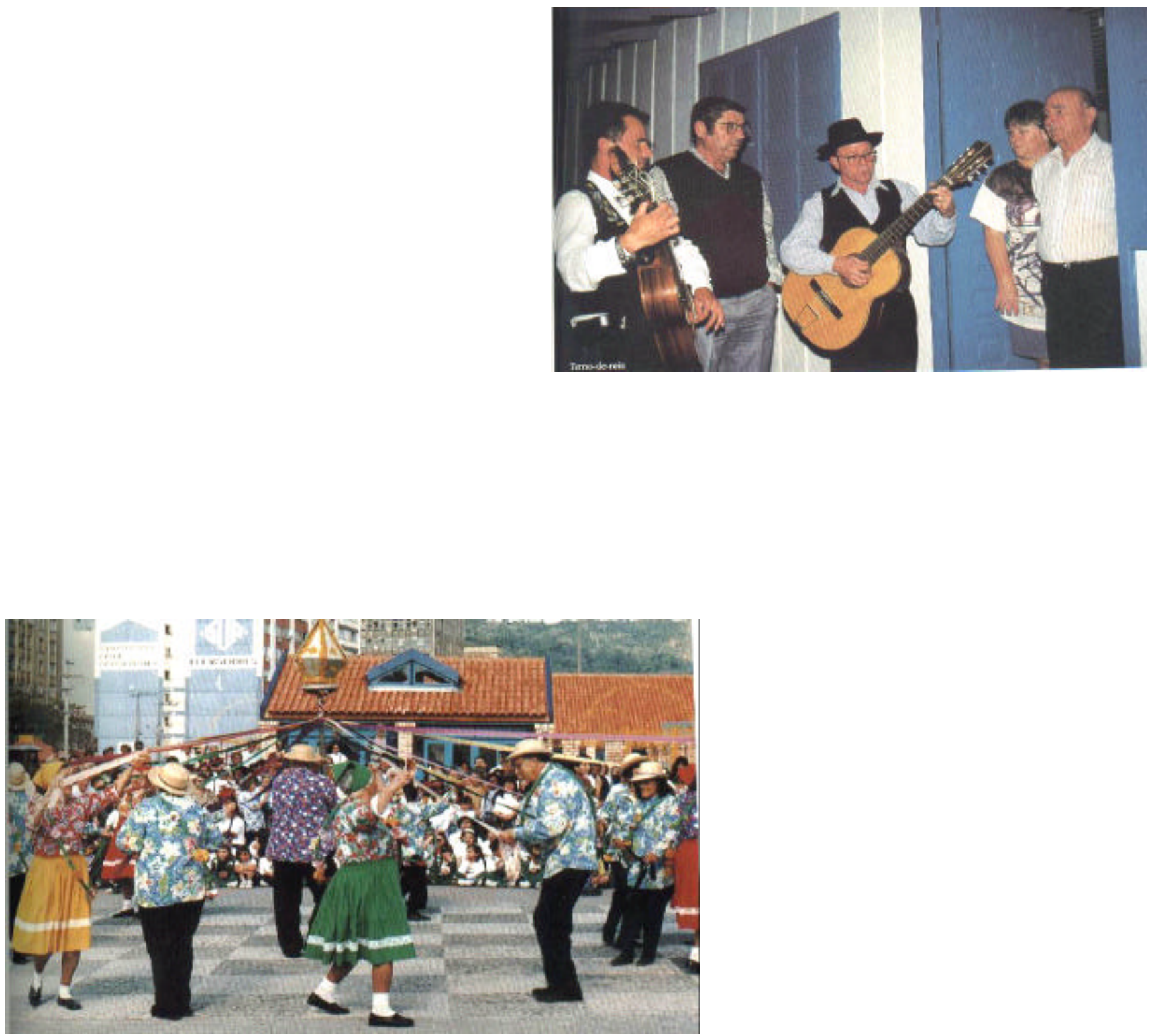

Pau de Fita. Foto de Catarina Rudiger, 1998. Florianópolis, Ilha Açoriana. 


\section{Capítulo 3: Entrelaçando família, cultura e fonoaudiologia}

... o que cura não é a técnica, é a relação.

Molina-Loza.

Existe uma canção que precisa ser cantada em nossa cultura: a canção dos ritmos dos relacionamentos, das pessoas enriquecendo-se mutuamente e expandindo-se mutuamente.

Salvador Minunchin. 
A aprendizagem da língua materna insere a criança na história de sua sociedade, tornando-a produto e produtora da história de seu grupo social. Lane ${ }^{1}$ e Leontiev², afirmam que os significados produzidos historicamente pelo grupo social adquirem, no âmbito do indivíduo, um "sentido pessoal", ou seja, "a palavra se relaciona com a realidade, com a própria vida e os motivos de cada indivíduo.

A criança ao nascer não domina os códigos lingüísticos, suas manifestações resumem-se a expressões ligadas ao conforto e desconforto. Estas expressões começam a ser interpretadas pelas mães (ou quem faça a função materna), que já no primeiro mês de vida do bebê são capazes de distinguir as diferentes manifestações sonoras do bebê: fome, dor, manha etc.

No decorrer dos dois primeiros anos ocorre um domínio maior dos órgãos fonoarticulatórios (boca, língua etc.), dos códigos lingüísticos e dos movimentos corporais que permitem a criança criar formas diferentes de expressão e que necessariamente passarão pelo processo interpretativo de um sujeito já assujeitado pela linguagem.

A família é a mediadora entre o sujeito e a sociedade, pois é nela que aprende-se a perceber o mundo e a situar-se nele. Para o exercício

\footnotetext{
${ }^{1}$ LANE, Silvia T. M. Linguagem, pensamento e representações sociais. 13aㅡ ed. São Paulo: Brasiliense, 1997. Psicologia Social. p. 32-39.

2 LEONTIEV, Alexis. O desenvolvimento do psiquismo.1 $1^{\text {a }}$ ed. São Paulo: Moraes, 1978.
} 
desta mediação, a família passa por um constante processo de negociação com a sociedade. Estas negociações ficam explícitas na forma como cada um fala, já que

cada um fala de um lugar e é isto o que dá significado à fala. Falar de um lugar significa falar como portador de um lugar social - de classe, de raça/etnia e de gênero, os principais recortes que definem fronteiras sociais entre os sujeitos, entre tantas outras clivagens. Cada um desses lugares implica em uma fala particular, que precisa ser levada em conta. ${ }^{3}$

A família não é então algo natural, biológico, mas uma instituição criada pelos homens em relação, que se constitui de formas diferentes em situações e tempos diferentes, para responder às necessidades sociais.

As famílias pelas características já apontadas têm sido alvo de inúmeras intervenções dos fonoaudiólogos e outros profissionais de saúde, na maioria das vezes buscando-se um conhecimento da dinâmica familiar a fim de propor condutas "disciplinadoras" do corpo e das práticas educacionais de seus componentes.

$\mathrm{Na}$ Fonoaudiologia alguns autores ${ }^{4}$ referem-se à necessidade de

${ }^{3}$ SARTI, Cintia. Obra já citada. p.5.

${ }^{4}$ Ver: HILGERT, Celso F. Perspectivas da Inserção da Fonoaudiologia no Programa Nacional de Saúde. In: Anais do Encontro Nacional de Fonoaudiologia Preventiva e Social. São Paulo: Conselho Regional de Fonoaudiologia, 2a região,1988. ANDRADE, Claúdia R.F. Ações Fonoaudiológicas na Saúde Materno Infantil. São Paulo: Lovise,1996. Fonoaudiologia em Berçário Normal e de Risco. p.25-42. WITTER, Geraldine. Implicações sociais da linguagem. In: Anais do Encontro Nacional de Fonoaudiologia Preventiva e Social. São Paulo: Conselho Regional de Fonoaudiologia, 2a região,1988. PERISSONOTO, Jacy. Atuação fonoaudiológica com o bebê prematuro: acompanhamento do desenvolvimento. In: ANDRADE, Cláudia C.R.F.(org.) Fonoaudiologia em Berçário Normal e de Risco. São Paulo: Lovise, 1996. p.129-148. OLIVEIRA, Sandra M.R.P. Maternidade: experiência com curso de psicoprofilaxia e triagem fonoaudiológica. In: ANDRADE, Cláudia C.R.F.(org.) . Fonoaudiologia em Berçário Normal e de risco. São 
privilegiar-se a intervenção com pais no que tange às condições que propiciam um bom desenvolvimento da linguagem. Estas intervenções iniciariam desde o pré-natal e seriam direcionadas às mães, já que estas são consideradas as catalisadoras e propulsoras do processo da linguagem do bebê.

O lugar dado aos pais, no âmbito da Saúde Pública está diretamente atrelado à prática clínica do campo fonoaudiológico, a qual encontra-se vinculada a diferentes concepções de linguagem. ${ }^{5}$

Ao se conceber a linguagem como resultado do desenvolvimento motor, sensorial e cognitivo, a Fonoaudiologia aparece submetida ao discurso médico-pedagógico, cabendo ao profissional a aplicação de técnicas para a remoção dos sintomas. E assim, à família neste processo cabe informar sobre a criança, cooperar com o processo terapêutico dando continuidade aos exercícios em casa.

Nesta concepção, a atuação fonoaudiológica fundamenta-se nas seguintes idéias:

Paulo: Lovise,1996 .p. 227-234 . TANAKA, Cíntia e MESSAS, Cristiane. UTI Neonatal: experiência fonoaudiológica em um Hospital e Pronto-Socorro Infantil. In: ANDRADE, Cláudia C.R.F.(org.) . Fonoaudiologia em Berçário Normal e de risco. São Paulo: Lovise, 1996 . p.259-268

${ }^{5}$ Sobre a inter-relação entre concepções de linguagem e a forma de inclusão dos pais no atendimento fonoaudiológico ver: CORDEIRO, Denise. Da inclusão dos pais no atendimento fonoaudiológico de crianças com sintomas de linguagem: o que diz a literatura. São Paulo: 2000. [ Dissertação de Mestrado - Pontifícia Universidade Católica de São Paulo] 
há uma padrão de normalidade da linguagem a ser alcançado no processo terapêutico de crianças com sintomas da linguagem, e ao mesmo tempo, um padrão de funcionamento familiar a ser construído neste processo para o êxito do atendimento fonoaudiológico. Desta forma, os procedimentos clínicos utilizados pelo profissional visam respectivamente, a correção e a eliminação do erro e do sintoma de linguagem. ${ }^{6}$

Neste processo os fonoaudiólogos acabam objetivando a questão da linguagem, veiculando um conteúdo asséptico e neutro para a mesma. E, as questões sociais e culturais são tomadas como deficiências e fatores etiológicos.

A este respeito, Silva ${ }^{7}$ afirma que o fonoaudiólogo nas ações de saúde pública prioriza a normatização dos comportamentos e hábitos da população, participando da construção de uma imagem da mesma como infantil e despreparada.

O fonoaudiólogo, desta forma, auxilia no processo de discriminação social ao vincular um ideal de linguagem. Assim, possuir uma linguagem normal significa ter as habilidades orgânicas para reproduzir o padrão de língua estabelecido como correto. Fica evidente, como esta forma

\footnotetext{
${ }_{7}^{6}$ Idem, idem. p.8

${ }^{7}$ SILVA, Ana Paula B. Obra já citada. p.254-308.
} 
de purificar, higienizar, individualizar e neutralizar as complexas relações envolvidas com a comunicação, não só descaracteriza e anula o papel e a natureza social da linguagem, como contribuem para o controle e para a disciplinarização da mesma.

Como conseqüência desta abordagem descontextualizada, reduz-se também as explicações para a não efetivação do processo terapêutico, justificando-se 0 abandono pelas reduzidas condições financeiras dos pacientes e seus familiares, falta de compreensão do problema, desvalorização do trabalho fonoaudiológico.

Há uma outra possibilidade de conceber-se a linguagem tomando-a como funcionamento simbólico, sendo condição para significação e para o nascimento do sujeito. ${ }^{8}$

A criança ao nascer, encontra-se imersa em conteúdos simbólicos da língua e da cultura que irão constituir sua subjetividade, e, deste modo, transformá-la em sujeito da linguagem.

Linguagem e sujeito então não são transparentes e devem ser compreendidos em seus processos históricos de constituição (ideológico e inconsciente). Todo este processo de reprodução das relações sociais está baseado em como a criança ao falar constrói suas representações sociais, entendidas como uma rede de relações que ela estabelece, a partir de sua

${ }^{8}$ CORDEIRO, Denise T. Obra já citada. p.63 - 71. 
situação social, entre significados e situações que lhe interessam para sua sobrevivência. $^{9}$

Nesta abordagem, ainda segundo Cordeiro, o fonoaudiólogo procura compreender os movimentos da criança na linguagem, ressignificando o seu dizer ou seu não-dizer. Ele ocupa um espaço de interlocutor, no qual o trabalho de escuta é fundante, não tendo a função de 'ensinar' a criança a falar por meio de técnicas em que a doença se sobrepõe ao sujeito.

A função dos pais é redimensionada, não cabe a eles mais corrigir a linguagem do filho, importa escutá-los para reconhecer a representação que os pais têm de seu filho. Entendendo-se que "as histórias familiares que são contadas e recontadas pelos membros das famílias marcam de forma consciente e inconsciente os papéis que cada membro ocupará na família e na atividade discursiva., 10

Deve-se ter extremo cuidado de no trabalho de escuta parental não procurar adequar estes a um padrão ideal. Conforme Cordeiro, ${ }^{11}$ o trabalho envolve a criação de um lugar para que estes sujeitos tenham espaço para identificar e rever suas próprias questões na relação que constroem com os seus filhos, com o sintoma aparente, e, principalmente, com a dor, com o sofrimento que pode estar permeando esta relação.

\footnotetext{
${ }^{9}$ LANE, Silvia. Obra já citada.p.35

${ }^{10}$ CORDEIRO, Denise T. Obra já citada. p.51

${ }^{11}$ Idem, idem. p.68
} 
A lógica dos programas de orientação à família deve ser revista. Pois, ao entender que o conhecimento é fruto da atividade intersubjetiva, é no contato interpessoal que este ganha forma e sentido através da atividade interpretativa ${ }^{12}$ que envolve o encontro. Cabe ao fonoaudiólogo, como profissional interessado em conhecer e intervir com as questões de linguagem, mudar sua postura em relação à família.

O fonoaudiólogo, ao mudar sua escuta, poderá identificar de que forma o falar e o calar da criança são significados pelo adulto, como também a partir dos sentidos criados na cultura em que estão inseridos.

Pude a partir deste enfoque teórico, perceber que a mãe ao fazer a função materna com seu filho estará ressignificando aspectos de sua cultura, tanto para si como para a criança. E foi na observação deste processo de ressignificação realizado pelas mães que procurei entender o lugar dado à linguagem, conforme procurarei expor a seguir.

\section{Como nossos Pais: aprendendo a ser mãe}

No espaço da sala de espera pude identificar as formas como estas mulheres são reconhecidas, isto é, a partir das normas sobre o casamento e maternidade. São vários os autores que associam a construção da identidade feminina nos grupos populares ao espaço doméstico. Neste sentido o casar e ter filhos as coloca em outro lugar na

\footnotetext{
${ }^{12}$ A ação interpretativa envolve as ações de dar sentido, ajuizar, explicar, declarar o sentido
} 
comunidade, no qual o espaço da casa e do cuidar do marido e filhos ficam estreitamente ligados ao seu valor como mulher.

Quando tinha só três mães no posto, elas falaram um pouco de como tinham casado cedo, todas haviam casado com 15 anos e tido o primeiro filho entre 17 e 20 anos. Referiam que apenas o que era ruim, seria casar e ter filho direto. Todas referiram que não se arrependem, pois ainda eram novas e os filhos já estavam crescidos. (Diário)

O pai do garoto dá folga prá ele, quando eu penso que vou descansar porque ele vai dar o jantar para o filho, chego lá na mesa está toda virada. Digo para ele controlar o filho e a sujeira, sabe o que ele responde? Prá que eu tenho mulher em casa se não é para limpar tudo isso?(Diário)

Não casei muito nova. Mas não sei se é uma coisa muito boa, a gente tá sozinha qué casá, de repente aí muda tudo Stella, né.

É meu marido é bom, mas não sei é mais preocupação. É tem gente que não se preocupa, mas eu me preocupo com a casa, com meu marido, com as crianças.

Eu те preocupo, tudo certinho, né.

de, traduzir, explicar, representar . 
Não deixa nenhuma falha, eu sou assim, é o meu jeito de ser.

S: Mas o que seria ter falhas?

Assim, chegá tê café pronto, uma comida pronta, chegá a hora do almoço tá a comida feita, chegá tá a roupa passada, tá roupa lavada, tá os calçados limpos, tá a cama limpa, tá tudo limpinho. Tá tudo ajeitadinho, os filhos limpinhos, né, com a barriguinha cheia. Coisa chata o marido chegá cansado, não tem um café pronto. Qué roupa prá vesti não tem, qué uma comida prá comê não tem, né. ....Eu acho tão feio a mulher que não cuida da casa e dos filhos.

S: Mas as mulheres daqui são bem ligadas nisso?

É oitenta por cento, tem algumas que ainda não cuidam direito. Aí não suporto.

Se vou numa casa e tá tudo bagunçado, aí prá mim é aí que a mulher mais relaxada, eu já penso assim, entendeste?

Não queria ser assim, mas eu sou assim. A minha mãe era assim teve onze filhos, mas tudo muito bem, né. Muito limpinho. A gente já foi criada desta forma, entendeste?(Janete)

Sobre os filhos, encontrei desde mães com vários filhos até mães que tinham um e estavam pensando se ainda teriam mais, na maioria das vezes o ter, mas estava um pouco ligado ao sexo da criança.

Ah, a mãe tem seis filhos e seus netos são mais velhos que este seu filho de 1 ano e 2 meses, aí a Fátima brincou que quando ela casou não tinha TV, mas eu disse que hoje tinha. Ao que as outras mães 
responderam que agora que tem TV a gente aprende coisas diferentes, e riram. Mas ela falou que não tinha macho só "fema" e então como encarreirou ela estava atrás do macho, já que sua mãe teve nove, elas tinham sido ao contrário já que a mãe só tinha macho e no final teve fema. (Diário)

Uma mãe pede para outra se podia pegar seu bebê, falava assim: Deixa eu pegar que eu não tenho machinho em casa. Uma das mães comentou, nossos maridos são loucos para ter menino. Eu comentei, é eles querem ter menino e no fim se grudam nas meninas. É eu tenho duas meninas e são todas dele, não posso falar nada. Lá em casa também, não posso falar nada que a Sônia já diz, Ah mãe deixa o pai, deixa. Uma outra encerra o assunto dizendo, parece que filho homem é mais da gente.(Diário)

Novamente aparece o traço da continuidade, as mulheres continuam casando na mesma idade que suas mães, mas já há espaço para planejar seus filhos.

Falou que sua filha era muito novinha, tinha dezesseis anos e já estava casada há um ano. Comentei que ela também deveria ter tido 
filhos novinha. É mas eu não quero isso prá minha filha, quero que ela aproveite bastante.

Aquela também que ficava grávida, não tinha jeito queria corrê, mas não tinha jeito pegava. (Laura)

Há a constante circulação entre novas formas de ser e o peso da criação. Todas as mães entrevistadas fazem este movimento no qual buscam independência das mães, mas no dia-a-dia identificam em suas práticas o jeito da mãe.

Eu não tive muito contato com a minha mãe, ela mora do meu lado, mas não teve muito tempo de me dá assessoria. Não Stella, eu criei, eu tô criando meu filho como eu acho que dá, da maneira mais correta. (Simone)

S: Quem te ajudou a aprender a lidar com ela ou foi você sozinha $\operatorname{assim} . .$.

É eu tive a filha assim. Como minha mãe mora por perto, ela veio mas pouco tempo, é minha sogra que às vezes vem visitar. Mas a gente procura eu e o pai dela assim a dá uma boa educação que a gente acha legal prá ela, assim né. Eu sempre tive educação, então tudo o que eu vejo que não foi legal prá mim, eu não quero prá ela. Então a 
gente sempre busca dá o que a gente acha que é a melhor forma, eu sei que sempre tem os acertos e erros mas a gente sempre.....

S: E como você fazia com as suas dúvidas?

Olha eu sempre procurei ler bastante e eu não sei porque mas quando sobrou alguma coisa eu sempre procurei levar no médico particular. Sentia mais segurança, não sei.

É como eu já falei a gente não tem influência da mãe nem da sogra. (Kátia)

S: E o que você aprendeu com a tua mãe assim, pra faze com teus filhos?

Eu porque com a minha mãe não aprendi nada, porque eu perdi minha mãe com sete anos. Então eu aprendi muitas coisas sozinha, porque eu não tive muitas coisas, porque não existia apoio como tá tendo agora na cidade. Mas o que eu posso fazê pelos meus filhos, tô fazendo de tudo. $(\text { Laura })^{13}$

A gente só entende a mãe da gente depois que tem filho. É só aí que a gente valoriza o que elas fizeram. (Diário) 


\title{
Do desejo da mãe ao desejo da criança: o caso da chupeta
}

\begin{abstract}
As histórias sobre o uso da chupeta manifestam também sempre uma ambigüidade do tipo será que está certo por aí. Neste momento, também vêm os conhecimentos tradicionais (minha mãe usava isso) e os modernos, assimilados via serviço de saúde ou consumo.
\end{abstract}

A chupeta é inserida como "um santo remédio" para sossegar a criança ou mantê-la quieta. Elas relatam que a chupeta "é uma mania dada pelos pais", mas que às vezes, mesmo eles (pais) querendo, a criança não pega.

“ só que tem uma coisa, a criança que pega o peito não pega o bico, bem que eu tentei com meus dois filhos. ”(Diário)

As maiores divergências ocorriam na forma de tirar a chupeta. Algumas vinculavam o seu uso ao medo da sucção digital.

"tenho tanto medo que ele sem a chupeta pegue o dedo, pois esse não tem como tirar." (Diário)

\footnotetext{
${ }^{13}$ Laura, 40 anos, mãe de cinco filhos, nasceu em Zimbros, seu marido é pescador e ela trabalha fora apenas na temporada.
} 
"tentei tirar quando ela tinha 3 - 4 meses e a moça do posto disse que eu tinha de tirar a chupeta, senão ela iria ficar gorda, e que a chupeta é uma porcaria. Fui ouvir, tirei a chupeta e ela colocou o dedo agora tiro como o dedo?” (Diário)

Algumas delas tomam para si a responsabilidade de tirar a chupeta.

“ minha mãe queimou a chupeta no fogão na minha frente.” (Diário)

“na do Adriano eu coloquei pimenta para tirar, ele ficou todo assado, mas deixou. Isso foi coisa da minha mãe.” (Diário)

“dei para o cachorro e para a gente ver como marcou, dormindo a garota dizia: mamãe, mãe, mata o lobo. E ela só tinha dois anos, mas largou.” (Diário)

"eu piquei a chupeta na frente do meu filho, peguei uma tesoura dizendo pra ele agora você não tem querer, tá aqui a chupeta toda picada." (Diário)

O fato de conseguir fazer a criança largar a chupeta de certa forma qualificava ou desqualificava a mãe frente às outras.

“ eu nunca tive o menor problema para tirar é só decidir e pronto." (Diário) 
"o meu, além do bico ele tem a fralda para cheirar e que não pode ser lavada. Parece que ele faz isso para eu passar vergonha, principalmente lá na igreja. Lá eu escondo o paninho porque senão eles vão me achar uma porca. Morro de vergonha." (Diário)

Há ou parece haver uma norma para a época de tirar-se a chupeta, em todos os dias nas conversas elas colocavam a idade limite de três anos.

"depois dos três anos a boca fica funda e os dentes entortam." (Diário)

“ eu tirei do meu só agora que ele tem 3 anos, porque criança nessa idade já tem desejo, então dá para tirar trocando, ele ganhou um aquário." (Diário)

O entrelaçamento entre o desejo da mãe e o da criança, acaba norteando a tirada ou a permanência da chupeta.

“não adianta a criança só larga quando quer.” (Diário)

“costume não tem como tirar.” (Diário) 


\section{Fala: um dos lugares do desejo da criança}

Em nenhuma das observações ou entrevistas realizadas, houve comentário sobre questões relativas ao falar das crianças de 0 a 2 anos. As questões de linguagem estão imbricadas no que é esperado no comportamento das crianças e no reconhecimento que este comportamento do filho traz diretamente para as mães.

Nos momentos descritos a seguir, pude perceber que nos vários lugares em que a criança ocupa no decorrer do seu desenvolvimento, a fala parece ter um lugar específico na construção do lugar do bom filho, assim como outros comportamentos.

Os recém-nascidos que chegavam ao posto, na maioria das vezes, estavam envoltos em várias mantas de lã ou em coberto e havia todo um movimento de proteção do bebê.

“ a criança enquanto dorme está crescendo.” (Diário)

“os antigos já diziam, criança pequena é que nem pão quanto mais coberta mais cresce." (Diário)

Neste dia havia um menino que só dormia de bruços, no colo da mãe e ela tinha que ficar andando para embalá-lo. As outras mães falaram que ela não podia dar balda assim, senão depois ela não iria agüentar, ele iria querer sempre. Todas concordaram com a colocação 
"afinal quem ensina é a mãe." A mãe respondeu "Ah tadinho ele é tão querido, $e$ não está me custando nada."

Uma mãe comentou que na sua casa o bebê ficava o tempo todo no quarto, porque ele ainda era muito frágil para ficar no meio do barulho. Já outra mãe comentou exatamente o inverso, que levava o filho para onde fosse em casa a fim de que ele fosse ganhando resistência.

Nestes recortes percebi que a criança pequena é tida como frágil, cabendo à mãe "moldá-la" tanto para que ela ganhe resistência ou mude comportamentos. ${ }^{14}$

A criança como espaço de reconhecimento do valor da mulher apareceu em vários momentos.

"o bebê nesse momento começou a rir e se mexer no colo da mãe da menina, e ela falou 'nossa como ele é risonho e esperto ainda tão novinho'. A mãe do menino ficou supervermelha e risonha, dava para ver como ela estava feliz.

A amiga virou e disse: ó, ficou toda prosa. Também ele só tem que ser esperto você não tem nada para fazer além de ficar em cima dele. Ela tem um ciúmes dele, eu chego lá para pegá-lo e ela já diz deixa, deixa, não sei como hoje ela tá deixando.

${ }^{14}$ Sobre a visão da criança como ser frágil e que precisa de constantes cuidados ver: LOYOLA, M. obra já citada,p.127 e PEREIRA, Francisco. Obra já citada,p.83. 
Mas a amiga dela podia falar à vontade, tinha a impressão de que esta mãe estava plena, orgulhosa pelo olhar e reconhecimento que ela e seu filho estavam tendo." (Diário)

Este tipo de reconhecimento do grupo, já havia aparecido na questão da chupeta quando uma delas tinha falado quando estava só comigo e o pessoal do posto que não estava tendo muito jeito para tirar a chupeta do filho, mas quando estava com mais mães comentou que nunca teve dificuldades, era só decidir e pronto.

A sala de espera tinha uma dinâmica interessante, antes do médico chegar as mães ficavam agitadas e tentando controlar os filhos, as conversas nestes momentos restringiam-se a comentários rápidos sobre o que os filhos têm, de onde eram, a fala das crianças era pouco significada e o que mais se ouvia era: fica quieto, não faz isso que vai se sujar e a chupeta era muito usada para apaziguá-los.

Observei durante todo o período que as mães em sua maioria não levavam brinquedos para as crianças se distraírem enquanto esperavam, estes parecem ter função em outra fase do desenvolvimento, com as crianças pequenas (zero a dois anos) a fala da mãe era contendo a criança, associado a comida e chupeta que envolviam a criança.

Parece que ser bom filho é não falar, não responder. A linguagem acaba tendo menos valor que o ato, pois o ato seria obedecer, 
aceitar, não sendo bom enfrentar a autoridade. Isto também apareceu nas entrevistas.

"O Adriano irmão da Brenda já tem 8 anos e eu comentei que ele era muito querido, pois estava ali desde uma hora e já eram quase seis. A mãe ficou toda orgulhosa, mas rebateu 'que nada ele é um perigoso, é respondão, malcriado, só é bom na escola, tem 8 anos e tá na terceira série.'

Depois ela seguiu contando que ele sem ela mandar trabalhava toda tarde com seu sogro, descascando marisco, e comprava seus brinquedos se ela dissesse que ele precisava de meias, era ele quem comprava com o seu dinheiro além de todo o dia lavar a louça do almoço para ela. Eu comentei se isso não era ser um bom menino? Ela só riu.”(Diário)

“A gente controlava só com o olhar, não precisava nem batê. Outro dia falei para minha neta, se eu respondesse como ela, já tinha ficado sem boca. Só tratávamos nossos pais por senhor, senhora, eles hoje não, usam tu prá tudo. Responder então, nem pensar. Chamar de antigo como chamam a gente, ia ficar sem boca. A gente sabia se comportar, chegava na hora do almoço se reunia todo mundo, se servia e comia todo mundo de boca fechada, sem algazarra.

S: Então ser educado tinha a ver com não falar, não responde? É.(Ivana)

Esta fala também aparece em outras mães, sendo que algumas colocam como uma crítica a este modo de ser e outras como uma norma padrão. 
"É eu acho que é característico daqui é, não sei como que é, talvez pela educação deles, eu aprendi que eu nunca ia contrariar meus pais por nada desse mundo.” (Kátia)

"Eu faço diferente do meu pai.

Que eu me lembre qualquer coisa que a gente aprontava, se a gente não aprontava, entrava na mangueira do mesmo jeito. Então isso com meus filhos eu não faço." (Laura)

“Eu acho que uma pessoa bem educada é que não fala palavrão, entendeste. Se porta bem, conversa com todo mundo, cumprimenta, né. Uma pessoa bem educada eu acho que é isso, não ser uma pessoa respondona, fala palavrão, xinga.” (Janete)

"E porque vocês comiam sem falar?

Porque não tinha novidade para contar. A mãe ficava em casa, o pai saía pra pescar e às vezes voltava às quatro da tarde, então chegava em casa, comia e dormia para trabalhar depois, e nós íamos descascar camarão, trabalhávamos mas era divertido. Eram mesas compridas em que ficava todo mundo junto." (Ivana)

\section{Era então no espaço do trabalho que a fala circulava mais e provavelmente era ali que se criavam e discutiam as normas da comunidade.}

“Antes todo mundo falava a mesma língua todo mundo se conhecia, e as coisas que podiam eram para todos. Hoje a gente não pode confiar mais nos filhos, pois eles dizem uma coisa e fazem outra, ou o pessoal da rua puxa para o outro lado. 
E seus pais confiavam em vocês?

Claro, não tinha porque não confiar as regras eram para todo

mundo." (Ivana)

A mudança nos padrões de produção aparece na forma das diferentes regras vigentes hoje e talvez leve à criação de novas necessidades relacionadas à linguagem, como aprender inglês ou não querer ser manezinho.

Esta aparente invisibilidade da linguagem levou a questionamentos em sala de espera, e neste âmbito também aparecem duas visões: a mais presente, de que a criança aprenderia sozinha, cabendo a mãe apenas auxiliar e no outro extremo, a mãe que ensina.

"Eu dou o peixe, mas acho que a gente não precisa fazer nada, pois tudo tem seu tempo certo. Como meu menino, primeiro andou, depois nasceu os dentinhos e agora ele tá falando cácá." (Laura)

"Ah, eu já acho que a mãe tem de esforçar a criança, mas só depois que ele falar a primeira palavra. Quem tem que começar é ele, depois disso a gente puxa."(Janete)

Reaparecem aqui as mesmas questões que envolviam a inserção e retirada da chupeta, a questão do tempo e do desejo. Parece que há o tempo de se ter atenção ao falar.

"O menino que estava no posto com a mãe era bastante observador e mexilhão como qualquer criança de dois anos. Só que não falava nada, 
e quando eu falei para a mãe: como ele é quietinho, não fala nada? Ela ignorou totalmente a pergunta, alias ninguém ligou para o fato dele não falar nenhum som." (Diário)

"Tudo tem a idade, tem um certo tempo de fala, o tempo realmente que a criança vai aprendê de tudo.” (Janete)

Estes tempos que vão nortear as diferentes formas de disponibilidade das mães.

“Tem uma fase que eles tão pequeno. Qué dizê a fase que eles tão com seu ano, seu ano e dois meses, quatro meses, eles brincam sozinhos, então não precisa se preocupar. Tu vais te preocupar se eles tão dentro de casa, tu vais te preocupá em eles não mexê nas coisas de perigo. Tudo é uma fase, entendeste. Aquela minha fase de eu ter todo o meu tempo disponível já passou.”(Janete)

Mesmo as mães achando que a criança desenvolve sozinha, colocam que têm uma função importante no desenvolvimento da fala dos filhos.

“Eu acho que eu ajudei, porque ninguém... geralmente, eles dão o passo como fala, como anda, eles dão o primeiro passo mas incentivo ajuda muito, entendeste. E eu incentivava eles a falá, eu ajudava, eu tenho pra mim que eles falaram rápido todos os dois. Eu ajudava assim, por exemplo, assim, aí diz qualquer coisa ou queria comer, vamos supor ele fala eme, eme. E eu falo: não, é come, como, né. 
Bota a fralda, vamos supor, aí em casa ele falasse pápá ou mamã. Assim, dessa forma assim eu tenho pra mim que ajuda até a criança soltá a língua. A falá declarado e falá certo, né. Eu tenho pra mim que o incentivo da mãe ajuda muito nessa parte aí do falá, até do andá.” (Janete)

“Hoje ele começou a chamar mamãe, eu disse, João vamo tomá banho com a mamãe, vamo. Mãmã.

E o que você acha que o levou a falar?

Que eu repeti isso: Vamos tomá banho com a mamãe. Porque ele ama banho."(Laura)

Estas mães relacionam a emergência da fala e sua função, a atividades que envolvem prazer ou necessidade, cabendo a elas acompanhá-los neste processo.

Já no mesmo espaço convive outra noção, a de que a criança pode ser estimulada desde o ventre e que isto vai construindo suas condições para falar, sendo o papel da mãe, o de estimular este fala. Paim ${ }^{15}$ coloca que houve uma maior preocupação das mães em contactar com as crianças desde o ventre em decorrência da difusão de conceitos psicológicos em relação ao feto.

“Como você acha que ela aprende a falar?

Com a gente ensinando, repetindo , ajudando assim...

\footnotetext{
${ }^{15}$ PAIM, Heloisa. Marcas no corpo: gravidez e maternidade em grupos populares. In: DUARTE, Luiz Fernando e LEAL, Ondina F. Obra já citada p. 31-48.
} 
E acha que é assim desde pequena que você tá ensinando ou tem um tempo para falá?

Não, acho que desde pequenininha que ela começa, na gravidez ele (pai) já conversava com ela e a gente sentia que ela já reconhecia a voz, já conhecia a mãe e o pai desde nenezinho, acho que ela aprendeu.” (Kátia)

"E você acha assim, você falou que ele tá começando a falar tal, né. Tá, tá, já tá começando a pronunciar as primeiras palavrinhas. Tem som, grita, fica nervoso e pã e fica, ele já tá colocando em prática as cordas vocais dele prá trabalhá bastante.

E como você acha que ajudou ele?

Estimulando desde a barriga, já. Desde o período, é desde via a placenta que a gente conversava muito com ele. E ele respondia, se movimentava, ficava quieto, e quando eu tive meus problemas na gravidez falava com ele. E eu falava prá ele assim, filho não se mexe muito senão a mãe não vai ter como segurar essa gravidez, eu sempre conversei com ele e ele ficava quietinho. O Giovanni entende tudo, a gente conversa, a gente acha assim, muitas mães acham que não entende, mas entende sim. Tu conversando assim, mas uma coisa que eu acho que não resolve é gritá. Gritando ele fica mais nervoso." (Simone) 
Nas suas diferentes visões sobre a emergência da fala, estas mães sempre colocaram a necessidade de se olhar a criança, não a pontuando como um ser passivo no processo da aquisição da linguagem.

Convivendo neste espaço também há a tradição. Quando perguntei se existia alguma simpatia para a criança falar às mães, várias responderam contando do cação.

“O primeiro peixe que a criança tem de comer é o cação.

É o nosso tubarãozinho, usam muito ele em posta, ele tem uma espinha fina.” (Diário)

Estas práticas e sua continuidade ficam a cargo das avós, as mães negam usar este tipo de prática e quando o fazem remetem à influência materna. Sobre as simpatias ninguém entende muito do assunto, reforçando sempre a coisa do ser antigo, até nas entrevistas isto é recorrente, apenas uma descreveu como é a simpatia.

"Com que idade faz a simpatia pra fala?

Antes dele falá, né. Antes em casa ele comeu cação não porque eu comprei porque eи queria que ele falasse. Eu comprei porque a gente come, né. Acho que foi feito ensopadinho, eu não lembro mais, só lembro que eu fui na casa da minha mãe e eu dei o cação. E eu vi que não demorou muito tempo ele já tava falando mais, mais rápido, não sei se era o tempo dele falar mesmo ou se era o cação. A minha mãe é 
que diz que o cação ajuda a criança a falá. O Gabriel comeu mais cação que o Lucas, e ele falava mais que o Lucas, sempre falou mais. Pode ser.

Porque será o cação?

Deve ser porque tem boca grande. Eu não sei te explicar, a minha mãe acho que sabe. A minha mãe é que falava, realmente eu dei o cação por dá e realmente funcionou. É só ele que pode dizê, eu acho que isso já vem de antigo aqui, né."(Janete)

Na sua fala, Janete circula entre os dois espaços que envolvem Zimbros, o da tradição e o da modernidade. Interessante nesta prática a identificação da simpatia com a atividade do pescador, e do local, pois cação era o peixe que mais dava ali na enseada, segundo elas.

Como instrumentos na reflexão destas mães entram principalmente a televisão e a escola, ao mesmo tempo que propiciam uma mudança de comportamento, aumentam e restringem suas opções de ação. Algumas colocam isto como um fator negativo e outras como a possibilidade de ser melhor mãe.

Hoje a gente não pode confiar mais nos filhos, pois eles dizem uma coisa e fazem outra, ou o pessoal da rua puxa para o outro lado. A gente conversa com eles, mas eu não confio no que eles dizem. 
E os seus pais confiavam em você?

Claro, não tinha porque não confiar as regras eram para todo mundo.(Ivana)

Hoje pra educa tá mais dificil, porque hoje assim tem muita coisa... Naquele tempo, não, naquele tempo tudo era mais dificil assim, não sei porque nóis não tinha televisão e hoje, né. A gente educa de um jeito, mas às vezes eles já querem fazê, eles têm sua própria opinião entendeste?

É diferente, eu não sei quando eu era pequena, eu obedecia minha mãe, obedecia meu pai. E hoje em dia eles já não querem obedecer, eles são teimosos assim. Eu não sei acho que é porque as coisas tão mais evoluída, eles aprendem as coisas mais fácil, eu não sei.” (Janete)

Estas diferenças dificultam a criação dos filhos, levando-as a abandonar certas práticas e buscar formar outras redes de apoio para a criação dos filhos, envolvendo escola, posto, mães de sua idade para a legitimação de suas práticas.

Uma forma de educar que sofre a marca do sistema é a da violência pedagógica. 
"Antes a gente podia bater no filho que ninguém se incomodava e assim eles aprendiam, se não consertar enquanto é pequeno aí que entorta, como dizem é de pequeno que se torce o pepino." (Diário)

"Eu tenho marca de chave de fenda nas costas que o meu pai jogava.” (Diário)

"Só uma avó presente não concordou dizendo que criou nove filhos e não batia em criança dessa idade (seu neto tinha dois anos), só que a filha dela bate com a pá no filho, ele não quer comer, ela bate e agora ela sempre coloca a pá na mesa e ele come.” (Diário)

"O meu filho tinha a mania de tirar tudo debaixo da pia, chegava na cozinha tinha poça de óleo e ele no meio, aí fiz uma coisa amarrei as mãos nas costas e nos pés dele e sentava-o na frente da televisão a manhã inteira durante oito dias, depois soltei pra ver, quando ele chegou na cozinha olhou para a pia e falou não mãe. Hoje com as minhas netas que moram comigo, não posso nem bater na de cinco anos que chega para mim e diz bate, bate que você vai para a cadeia, eles ficam ouvindo isso na televisão, tudo besteira, a televisão só ensina besteira." (Diário)

"Ah, eu não tenho isso, a minha neta deu um tapa levou outro na cara.” (Diário) 
“Eu não bato não, é muito raro eu bater neles, só se eles aprontarem muita coisa assim daí eles apanham. Aí se o pai deles tá junto, só dá um grito assim e pronto é quem mais pode ficar quieto." (Laura)

Costa $^{16}$ coloca que a sistemática intervenção sobre as famílias levou a uma desestruturação desta, tornando-a cada vez mais dependentes dos especialistas para solucionar seus problemas.

Este autor pontua que a família também foi uma forma das profissões se afirmarem sobre a população, referindo que as intervenções sobre a população no inicio deste século foram maciças e regulares. Esta desqualificação do saber da população sobre os filhos, transpareceu do discurso das mães no uso recorrente da palavra difícil para referir-se ao que é ser mãe, trazendo para o debate a forma como os profissionais podem auxiliar neste processo.

A formação de profissionais preocupados com o resgate das culturas locais e a busca do fortalecimento das relações comunitárias é presente nas discussões sobre saúde, mas questiona-se se esta visão não é engolida pela lógica do mercado de saúde que incentiva a medicalização das questões de saúde.

${ }^{16}$ COSTA, Jurandir F. Ordem Médica e Norma Familiar. 2ª ed. Rio de Janeiro: Graal,1983.p.151. 


\section{Atividades do Cotidiano}

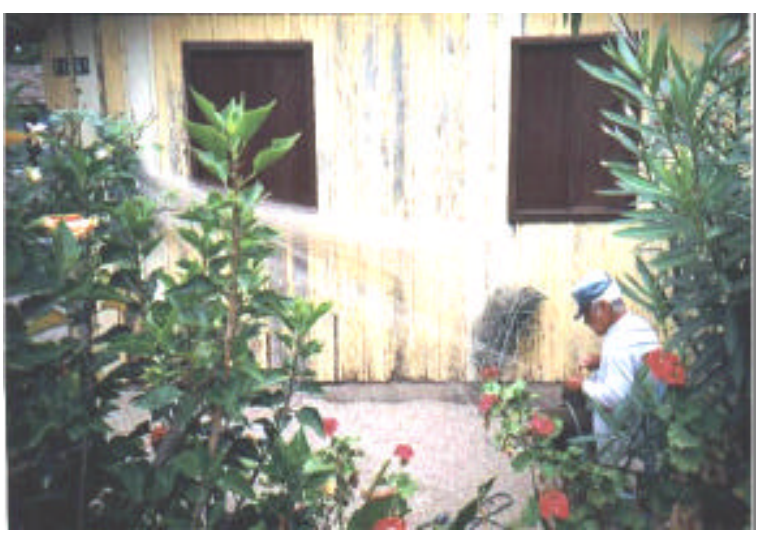

Pescador mais velho tecendo rede para pesca artesanal na Península de Zimbros.

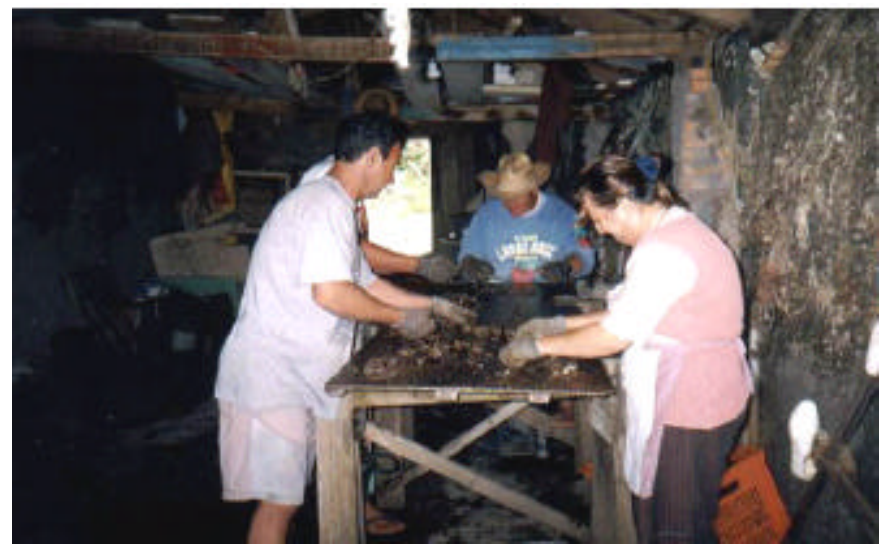

Seleção e limpeza do marisco de cultivo feita por homens e mulheres em ranchos. 


\section{Capítulo 4: Unidade de Saúde como campo de ressignificações}

O conhecimento (....),exige uma presença curiosa do sujeito face ao mundo. Requer sua ação transformadora sobre a realidade. Demanda uma busca constante. Implica em invenção e reinvenção.

Paulo Freire, 1977. 
As atividades de Saúde Pública sejam elas de promoção, proteção ou recuperação, devem estar voltadas à problematização das questões do cotidiano. Em relação a este, deve-se buscar que

as pessoas tenham direito a respirar ar limpo; às imunizações: à alimentação sem pesticidas; a proteger-se das epidemias, a não serem estimuladas ao consumo farmacológico descontrolado, a serem amparadas em circunstâncias de desastres naturais, a serem informadas sobre os riscos que correm sobre os agravos à sua saúde e à da coletividade, ao lazer, à moradia, ao trabalho, à educação, dimensões fundamentais para se criar circunstâncias promotoras de uma comunidade com Saúde Pública. ${ }^{1}$

Todo este processo depende além de decisões políticas, da criação de espaços comunicativos que possibilitem aos indivíduos colocarem-se sem quaisquer constrangimentos. Habermas ${ }^{2}$ coloca que se deve buscar relações em que os sujeitos, através de uma atividade lingüística, desvendem suas concepções para chegarem a um consenso ${ }^{3}$ sobre algo.

\footnotetext{
${ }^{1}$ VASCONCELLOS, Maria da Penha C. Os (des) caminhos da formação sanitária e os direitos sociais: uma reflexão a partir da Escola de Saúde de Minas Gerais. São Paulo; 2000. [ Tese de Doutorado - Faculdade de Saúde Pública da Universidade de São Paulo] 2 HABERMAS, Jurgen. Pensamento pós-metafísico: estudos filosóficos. Trad. Flávio Siebeneichler. Rio de Janeiro: Tempo Brasileiro,1990.

${ }^{3}$ Consenso no sentido aqui colocado marcar a não submissão a um saber , pontuando a busca de interlocuções possíveis que gerem a implicação dos sujeitos no processo, seja ele qual for econômico, saúde, educação, social e afetivo.
} 
Ao buscar as negociações realizadas pelas mães na criação de seus filhos, tendo como a perspectiva a relação entre linguagem e cultura, fui ao longo do trabalho percebendo que a ação da Unidade de Saúde extrapola a atividade clínica.

Há além do espaço assistencial todo um universo simbólico que envolve a legitimação das práticas populares, o acesso a novas informações e a negociação das demandas de profissionais-usuários tornando a Unidade de Saúde um lugar de reflexão,

"Ó nega a gente só conta com nós mesma.

Antes quando não tinha médico era tudo com o farmacêutico, hoje proíbiram eles de fazer tudo, remédio só com receita e eles não tão dando nada." (Diário)

"Como é que eles querem que a gente não se vire? Eu nunca vou trazer meu filho no médico com febre, eu faço uma coisa antes, pois se for espera....

S: E antigamente vocês faziam o que?

A gente levava na farmácia e resolvia tudo.

S: Não usavam chá?

Isso era bem antigamente, usavam chá.

É eu só uso guaco para bronquite." (Diário)

“...ele tá tossindo, dou cataflan sem ninguém ter receitado, senão depois só antibiótico dá conta" (Diário)

A fala das mães retrata o percurso dos serviços de saúde no bairro, desde a total ausência até a regulamentação dos prestadores de 
serviço, existindo a substituição de práticas caseiras por medicamentos. $\mathrm{O}$ principal problema desta evolução, segundo elas, está na exigência da receita, já estas mulheres não contam com pediatra sempre no posto (na época da pesquisa inicialmente a pediatra ia uma vez por semana, após ser substituída pelo novo pediatra que ia quinzenalmente).

A exigência das receitas para venda de medicamentos limitou a atuação dos farmacêuticos, estes conforme Loyola ${ }^{4}$ têm sido tradicionalmente substitutos dos médicos. A referida limitação, leva, conforme sinalizou os discursos das mães, às práticas de automedicação e à procura do serviço médico privado.

Outro resultado desta "evolução" da saúde é a desvalorização dos recursos tradicionais de saúde, as referências às parteiras e ao uso de chás, são evidências deste processo.

“... as parteiras são antigas, não enxergam direito, estão velhas.

Hoje é até um vexame não ter filho no hospital.

Vexame é ter o filho no carro junto com a sogra, o sogro e o marido, como eu tive." (Diário)

Em relação ao uso de chás, as mães comentaram que é muito complicado por causa do vento.

${ }^{4}$ LOYOLA, M. A. Médicos e curandeiros: conflitos sociais e saúde. São Paulo: Difel,1983.p.30. 
"faço chá de eucalipto e coloco embaixo da cama e só com o cheiro já faz o catarro sair." (Diário)

"Não dá, as crianças têm de tomar o chá e ficar quietas, mas elas não ficam..."

O vento também as levou a reclamar do médico, conseguindo mudar seu horário.

“onde já se viu o médico atender aquele horário, cinco horas é muito tarde para a criança tá circulando, ainda mais nesse frio."

A Unidade de Saúde de Zimbros expõe o dilema dos profissionais de saúde atualmente, originários de uma formação na qual o usuário é mero receptor dei informações e o profissional de saúde dono de um saber inquestionável, no entanto, é chamado tanto pelas políticas atuais de saúde como pela própria população a mudar sua postura.

Em vários momentos há apropriação do discurso médico, justificando as condições das crianças. Oliveira ${ }^{5}$ refere que $\mathrm{o}$ uso de termos médicos teria a intenção de diminuir a distância entre os profissionais e as mães, melhorando o atendimento prestado ao filho.

${ }^{5}$ OLIVEIRA, Francisco J. A. de. Concepções de Doença: o que os serviços de saúde têm a ver com isso? In: DUARTE, LUIZ Fernando e LEAL, Ondina F. Doença, sofrimento, perturbação: perspectivas etnográficas. Rio de Janeiro: FIOCRUZ,1998. P. 81-94. 
“ eles tão muito ruim pra comer. Acho que eles têm vermes.

S: Ruim como? Não comem nada?

Só comem por cima, depois só querem saber de bolacha e salgadinho, aqueles 'chips'. Por isso eu trouxe no médico, pra ver se tem vermes.” (Janete)

" ela tem baixo peso e dificuldade para mamar porque é prematura." ( mãe de uma menina de 1 ano - Diário)

“ vim ver se ele não estava anêmico, pois tenho sempre de ver, porque ele é anêmico de nascença. Todo o prematuro é anêmico. Isso é coisa que tem de cuidar sempre." (Diário)

Apesar destes discursos caracterizarem uma maior dependência dos serviços de saúde em sua fala, as mães manifestam sua demanda em direção aos profissionais e a necessidade do reconhecimento do seu saber sobre seu filho.

“o pediatra tem que escutar a criança toda, não é só olhar nos olhos." (Diário)

“... a mãe sabe o que a criança tem, se ela traz tem de ser ouvida.”

(Diário)

"médico tem de vir e atender, tem que estar aqui porque precisa ou porque tem amor.” (Diário)

"o pediatra pode nem dar remédio, o que importa é a fé que a gente tem." (Diário) 
O sentido destas frases evidencia a questão da escuta do profissional frente à população. Vasse citado por Barthes ${ }^{6}$ diz que

\begin{abstract}
escutar alguém, ouvir sua voz, exige por parte de quem escuta uma atenção aberta a esse intervalo entre o corpo e o discurso e que não se limita nem à impressão exercida pela voz, nem à expressão do discurso. O que é oferecido para ser ouvido por essa escuta é exatamente aquilo que o indivíduo que fala não diz: a trama inconsciente que associa seu corpo como espaço de seu discurso: trama ativa que reatualiza na palavra do indivíduo a totalidade de sua história.
\end{abstract}

Provavelmente é esta a escuta que é solicitada a nós, profissionais de saúde, escuta que como profissionais da saúde delegamos à Psicologia e à Psicanálise no âmbito individual ou à Sociologia e à Antropologia nas questões coletivas. Uma escuta que aposte na polissemia e tenha como condição a opacidade da linguagem, entendendo assim que os sentidos não são transparentes e 0 que podemos fazer são aprisionamentos provisórios dos seus sentidos, isto é, realizando a interpretação.

Existem assim dois movimentos em relação aos serviços de

${ }^{6}$ BARTHES, Roland. 0 óbvio e o obtuso. Trad. De Léa Novaes. São Paulo: Nova Fronteira, 1990. p.223. 
saúde: um que busca a homogeneização das condutas através do saber médico e outro que pede o reconhecimento da subjetividade de cada criança e mãe.

Neste jogo entre escuta e interpretação a possibilidade do diálogo, confronto e reciprocidade criar-se-ia um espaço comunicativo, não baseado numa relação estanque entre emissor-receptor, mas numa troca (conflitiva ou não) entre ambos.

Muitas vezes os profissionais preocupam-se em identificar as questões culturais e relacioná-las com sua prática, preocupação esta evidenciada pela Luciana ao comentar a adesão das mulheres às atividades de saúde da mulher.

... é, quinze dias embarcado, dez dias em casa depois volta, não sabe quando vai chegar. Aí elas não tomam o comprimido, o comprimido é 21 na cartela e o marido fica embarcado quinze dias, então pra que eu vou tomar o comprimido se ele não está aqui? Então ele chega amanhã , então eu tomo o comprimido. Ah, eu recebo a notícia, telefonema, carta que ele vai voltar, ele chega amanhã, aí eu vou na cartela tomá o anticoncepcional ou amanhã, e resolve? Não resolve, engravida e pronto, se não engravida é na sorte.

S: E a religião influencia?

É não aceitam, tem muita gente que queria fazer laqueadura, marido não quis. Camisinha então nem pensar. (profissional) 
...Comecei a fazer o preventivo aqui em 94, e nunca teve coleta desse tipo aqui, porque era só em Porto Belo ${ }^{7}$. Então depois que eu comecei a fazer devagarinho as mulheres começaram a procurar, né. Vinha uma, depois trazia a vizinha, mas é um processo bem lento, elas tem muita vergonha, por causa da religião.

....Porque elas freqüentam a Assembléia de Deus, usam saia comprida até os pés, usam manga curta no verão. Não cortam o cabelo, não se depilam, elas estão sempre escondidas debaixo da roupa, debaixo do pêlo, então vir até o posto fazer preventivo, ter que tirar a saia, tirar a calcinha, ter que se expor é eu acho que a religião interfere. Quem é católico ou ateu que não tenha nenhuma prática, vai para a praia de biquíni, ' shorts', para elas vir fazer preventivo não tem tanta vergonha por ser uma mulher que colhe, mas a questão da cultura interfere muito.(profissional)

Percebi nestas falas que o tipo de participação das mulheres nas atividades está atrelada a questões religiosas e/ou o trabalho do marido.

O acesso aos serviços de saúde com suas intervenções acarreta uma melhoria nas condições sociais, mas também trazem questões perturbadoras para a cultura local por propor novas prescrições e modelos para uma vida melhor.

\footnotetext{
${ }^{7}$ Bombinhas pertenceu ao município de Porto Belo até 1993 , após a emancipação é que começou-se a articular a rede de saúde local.
} 
Minayo $^{8}$ coloca que os profissionais devem se atentar para perceber que a população tem uma linguagem própria que reflete o saber da experiência, e que ignorar este saber é agir de forma preconceituosa. Correse o risco de voltar a utilizar os aspectos sociais e culturais como causa de doenças ou evidências de uma cultura atrasada, não se respeitando sua heterogeneidade e criatividade, já que como coloca Paim ${ }^{9}$

A cultura popular não constitui dimensão completamente autônoma, uma vez que se pode tomar elementos de outros universos para compor determinada visão de mundo, como por exemplo, na apropriação do discurso médico pelas mulheres de grupos populares. Em tais processos de negociação de significados, certas ressemantizações estão presentes.

Há que se estabelecer um constante diálogo com a população, tomando-se o cuidado de não desqualificar as práticas tradicionais, pois elas são o ponto de partida para a compreensão da dinâmica da comunidade já que a cultura de um grupo é produzida historicamente em condições sociais e materiais específicas.

Hellmann ${ }^{10}$ diz que a medicina tem sido responsável por um

\footnotetext{
${ }^{8}$ MINAYO, Maria Cecília. Obra já citada. p.37

${ }^{9}$ PAIM, Heloisa. Obra já citada. p. 35

${ }^{10}$ HELMANN, Cecil G. Obra já citada. p.87
} 
processo de medicalização do nascimento, estendendo-se as formas de cuidar do bebê, e neste processo tem ignorado os significados que as mulheres dão a estas experiências. Pude exemplificar esta questão no discurso dos profissionais abaixo.

A questão da amamentação, por exemplo, mãe passa para filha que passa para a neta que o leite é fraco. Não deve dar de mamá, não adianta que o leite é fraco. Isso olha graças a orientação dos médicos e a persistência da gente e até o pessoal daqui está mudando. (Luciana)

O médico quando faz pré-natal, diz: ó tua mãe vai vir, tua vó vai vir, vai te encher o saco, mas tu não dá bola porque o teu leite não é fraco. Se tu der a amamentação certinho e produzir leite, vai tá tudo bem. Não existe leite fraco. Vai começar a dar mamadeira, a criança não vai pegar nenhum nutriente, nenhuma vitamina essencial que é o que o leite materno dá, vai começar a ficar doente. (Luciana)

Como possibilidade de intervenção, busca-se a realização de programas educativos:

“... algumas vezes eu trazia vídeo cassete, fita e passava informações prá elas, sobre o bebê, o que ela sabe sobre a gravidez, e palestrinha sobre amamentação, trazia cartazes, isso eu consegui fazer algumas vezes, só daí é aquele transtorno tinha de emprestar a TV de Porto Belo, etc.” (Luciana) 
Berlinguer $^{11}$ chama atenção para que muitas vezes estas informações podem não ser acessíveis às pessoas de forma conveniente às suas expectativas, opiniões, preferências ou capacidades. Aí neste caso, a informação e o conhecimento pode aumentar as desigualdades sociais, na fala do próprio autor: "a informação pode agravar tais desequilíbrios se crescem o volume de conselhos e prescrições sobre o que poderia melhorar a saúde, sem considerar 'expectativas, opiniões, preferências ou capacidades."12

Todo este contexto pode justificar o estranhamento das mães frente à metodologia utilizada nesta pesquisa, foram recorrentes as questões sobre porque fazer a pesquisa em Zimbros. Elas chegaram a comentar que eu não conseguiria nada só ouvindo-as, o melhor seria fazer uma palestra e a seguir, conversar com elas.

“Tais só aqui , em pesquisa só aqui Stella? Não tá em outro postinho? S: Não, só aqui.

Tem em Bombinhas, Canto Grande.

Não gosta de ir prá lá? Gosta daqui, né?!” (Janete)

"Falei a elas que estava pesquisando mães de crianças de até dois anos para saber como se sentiam ao terem filhos e morarem ali. Duas falaram que era uma pena elas terem filhos maiores e a Karine perguntou se eu iria fazer palestras.” (Diário)

\footnotetext{
${ }_{11}^{11}$ BERLINGUER, Giovanni. Obra já citada. p.155-156.
}

${ }^{12}$ Idem, idem. p.156. 
"Hoje cheguei e dei com a cara na porta, a pediatra foi despedida devido a reclamações. Segundo uma auxiliar do pessoal de Bombas, já que em Zimbros não tem nada forte, nenhuma associação de bairros , o que o pessoal faz é descascar no pessoal do posto.” (Diário)

Nestas falas as mães reproduzem o discurso de que a população nada sabe sobre suas condições e de que precisa ser ensinada, e também a imagem de que outros lugares seriam mais interessantes de serem conhecidos, imagem esta reforçada pela fala do profissional de saúde. Assim, é natural que devido ao processo constante de desvalorização do seu saber, a comunidade acabe por não participar de associações de bairro ou reuniões do Conselho Municipal de Saúde.

"Outra coisa que não "e participativa é o conselho. Na última só tava os funcionários da secretaria que participam, eu não faço parte do conselho mas fui porque ia falar do SISVAN, como vai funcionar, verba, tal, mas não apareceram. Então, tem que incentivar mais, acho que de repente tem que tirar da prefeitura $^{13}$ a reunião, fazer no salão paroquial, sei lá, rodar o lugar ou avisar as pessoas mesmo de boca a boca, senão não adianta acontecer a reunião assim." (Luciana)

Ficando neste contexto o trabalho de promoção da saúde, pontuado no inicio do capítulo, cada vez mais distante, caso se perpetue a

\footnotetext{
${ }^{13}$ A prefeitura fica na praia de Bombinhas, distante de alguns bairros como Zimbros, Canto Grande e Mariscal.
} 
desqualificação da linguagem da população. Mas este pode ser um espaço também que auxilie na construção de novas formas de interlocução entre profissionais e comunidade, trabalhando com as questões do cotidiano.

A maior ênfase no trabalho sanitário localiza-se, como diz Certeau, na dimensão e ".....no lugar do corpo e da vida. Cuidar da nutrição, do entretenimento e da convivialidade que dá forma humana à sucessão dos dias e à presença do outro. Aqui, os corpos se lavam, se embelezam, se perfumam, têm tempo para viver e sonhar,... Aqui, as pessoas se estreitam, se abraçam e depois se separam. Aqui, o corpo doente encontra refúgio e cuidados, provisoriamente dispensado de suas obrigações de trabalho e de representação social (....), onde se inventam "modos de fazer": "Veja só como é que faço isso.... Na minha família, temos o hábito de......"14

\footnotetext{
${ }^{14}$ VASCONCELLOS, Maria da Penha. Obra já citada. p.128.
} 
A Unidade de Saúde e suas salas de Espera.

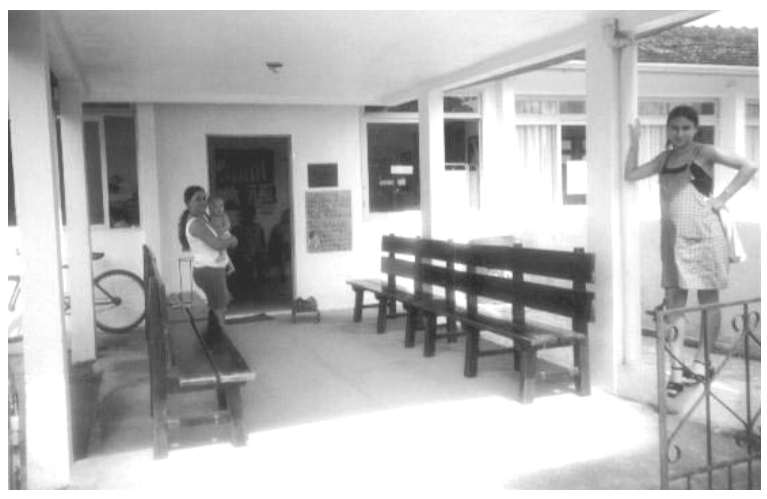

Sala de espera na parte externa da Unidade

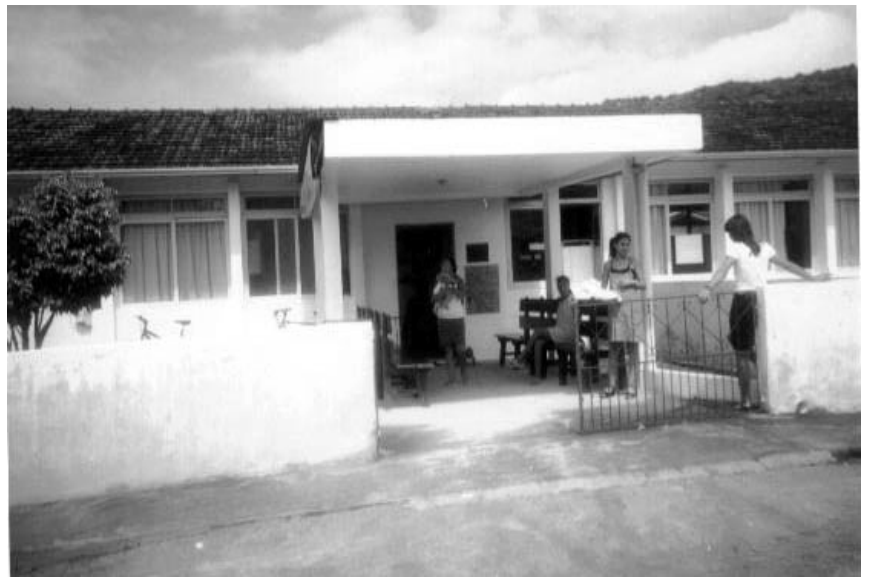




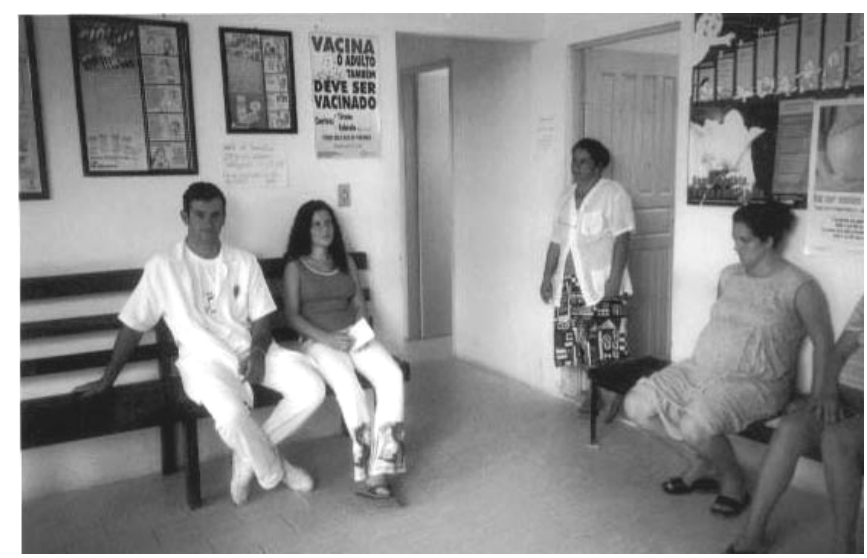

Sala de espera no interior da Unidade de Saúde

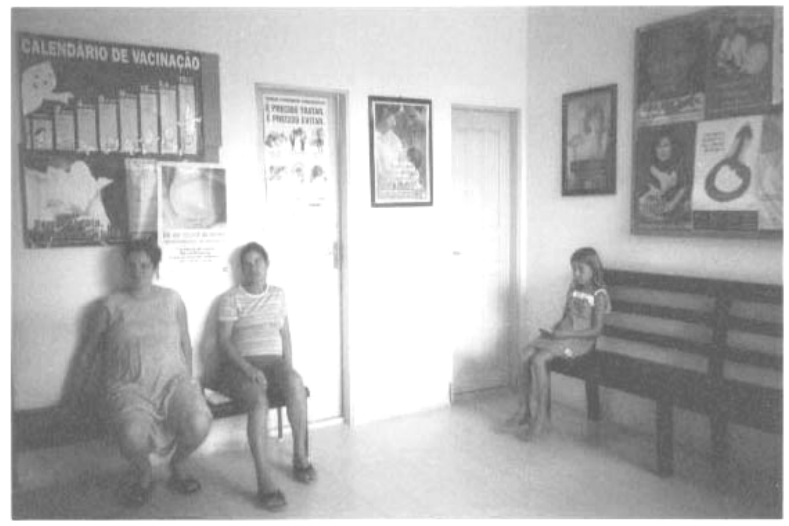




\section{Considerações Finais}

Sapentia: nenhum poder, um pouco de sabedoria e o máximo sabor possível.

Roland Barthes 
Ao concluir um estudo que busca a compreensão de um jeito de ser e estar no mundo, percebo que realizei um exercício de desapego às formas tradicionais de pesquisa fonoaudiológica; às normas e construções teóricas anteriores; principalmente às relações de poder entre profissional e população.

Coloco como exercício já que agora ao pensar nas considerações finais flagro-me em vários momentos questionando se não deveria colocar conclusões sobre de que forma este estudo auxiliaria na prevenção das alterações de linguagem nas crianças desta comunidade. E mais uma vez sintome raptada por um pensar fonoaudiológico que normatiza e instrumentaliza a linguagem, só que este rapto longe de tirar a legitimidade do trabalho reforça sua proposta já que como as mães também sou uma fonoaudióloga influenciada pela cultura de sua área que no momento valoriza pouco as dimensões sociais de sua prática.

Numa pesquisa como esta há sempre aspectos a serem melhor interpretados, alcançar o ponto ideal é questão de técnica e arte, nem sempre disponíveis. Mas espero que no final este texto tenha permitido o levantamento de questões sobre a atuação fonoaudiológica junto à população a partir de uma interpelação às Ciências Sociais.

No escopo deste trabalho esta aproximação possibilitou o conhecimento de metodologias de pesquisa que dão voz aos sujeitos ${ }^{1}$ e fornecem formas de analise que indicam um caminho a seguir na busca da compreensão da lógica local. O resultado deste processo é o que foi se revelando, isto é, o que as mães deram a "ver" em seu discurso e/ou ações e o que eu enquanto pesquisadora pude apreender.

\footnotetext{
${ }^{1}$ Voz manifesta até na escrita em primeira pessoa, opção extremamente difícil por sinalizar o tempo todo que toda a construção do estudo reflete apenas um modo de ver a realidade e que não é um estudo que propõe respostas, formas de fazer, mas lugar em que é posta a problematização.
} 
No caso desta pesquisa a lógica das práticas das mães sempre envolveu um processo de aproximação ou abandono das tradições. E já que este foi o processo identificado, cabia-me ir entrelaçando no decorrer do texto, passado e presente, nos vários contextos de vida destas mulheres.

As negociações realizadas pelas mães revestem-se de um cunho reflexivo sobre seus traços culturais e as influências globalizadoras representadas pela mídia, profissionais de saúde e turistas. Estas mudanças e a busca da própria identidade, manifestam-se na fala das mães que dizem que hoje cada um fala uma língua e que é mais difícil ser mãe, diferente do passado quando toda a comunidade partilhava dos mesmos valores falando a mesma "língua".

As mulheres mostraram-se ativas na construção do seu papel de mães, já que não se contentam em seguir as normas legadas, herdadas ou construídas em um status social. Descobrem-se a cada minuto como mães a partir da relação com seus filhos e o contexto cultural.

As suas práticas refletem a maneira como a comunidade entende as questões de linguagem. Em Zimbros há um silêncio em relação a esta questão, associado a um processo de desvalorização da cultura local, isto foi acentuado no contato com os meios de comunicação, com os turistas, profissionais de saúde e educação.

As questões de linguagem nas crianças estão atreladas ao desejo da criança de falar, a espera do tempo certo para falar, sendo mais evidenciados pelas mães de crianças de 0 a 2 anos os pontos que envolvem o uso da chupeta, a amamentação, alimentação e bom comportamento. Neste contexto cabe as mães a função de atender os desejos do filho, saber identificar a intervenção necessária a cada "tempo" da criança ou repassar normas de conduta.

E neste processo, a Unidade de Saúde apresentou-se como um espaço no qual as mães tem a oportunidade de legitimar suas práticas, redimensionar suas dificuldades, compartilhar suas dúvidas, sentimentos e 
conhecimentos. Estas ações observadas durante a pesquisa, ampliaram as reflexões sobre o lugar do profissional de saúde, mais especificamente o fonoaudiólogo, em relação à necessidade de desenvolver-se uma escuta em relação à população.

Uma escuta voltada à apreensão da realidade na qual está se inserido para que não restrinja sua atuação a ações de cunho informativo, mas substitua-as pela criação de espaços comunicativos que assim reconhecem que as mães detêm um conhecimento prévio e que é diferente, porém dotado de uma lógica a ser desvendada já que é resultante da relação mãe-criança-cultura.

No decorrer da pesquisa pude perceber que as mães já realizam ações que são "caras" aos programas de orientação fonoaudiológica a pais como: uso de chupeta para evitar sucção digital; estabelecimento de limites para o uso e retirada da chupeta; espaço para que a criança se expresse.

Nas suas explicações as mães usam de uma lógica compatível com seu contexto social, mais ou menos influenciado pelo discurso médico. Como por exemplo: "tem de tirar a chupeta até os três anos, senão os dentes entortam; ele grita já tá colocando em prática as cordas vocais dele."

Neste contexto comecei a refletir como chegariam a elas as orientações tradicionalmente dadas pelos fonoaudiólogos: empregar vocabulário acessível à criança; não falar por seus filhos; não se adiantar para interpretar ou adivinhar o que ele diz; procurar não atender aquilo que ele pede unicamente por meio de gestos ou choro, para que ele sinta necessidade de falar. Será que estas orientações não tomam como princípio de que existe uma mesma representação de fala para todas as camadas sociais? Será que uma mãe que está disponível para acompanhar os "tempos" do filho precisa receber um folder ou uma palestra com estas orientações? Não há uma resposta certa, pois não há garantias que certo comportamento vá sempre desenvolver a linguagem da criança, caberia-nos resgatar cada vez que fôssemos a uma comunidade, a função social desta 
linguagem, dando-nos o tempo para conhecer o lugar desta para a população. No caso de Zimbros pode-se detectar a valorização de um padrão de linguagem e a desvalorização da linguagem do nativo.

O desenvolvimento de uma atenção em relação à cultura da comunidade na qual estamos trabalhando não significa que haverá uma plena aceitação de todas as ações da comunidade. Mas sim, uma aproximação maior com a população para que esta ao sentir-se respeitada em seus valores possa aí sim colocar-se sem constrangimentos. Já que a vergonha e o constrangimento podem levar ao silenciamento de questões importantes sobre o desenvolvimento da criança.

Estabelece-se assim, o resgate de um fonoaudiólogo que ao trabalhar na atenção primária à saúde, precisa ser um generalista que valorize as questões de linguagem já que estas são a base para o trabalho com a comunicação e com suas alterações.

$\mathrm{Na}$ Fonoaudiologia atualmente, existe uma critica ao trabalho com comunicação, mas apesar disto ao estar com as famílias acabamos reproduzindo a noção de comunicação em um modelo calcado na emissão-recepção, na qual o papel de emissor privilegiado cabe sempre ao profissional.

A noção de comunicação defendida neste trabalho é a de uma comunicação baseada no respeito ao diálogo, com espaço para as relações de conflito e reciprocidade.

A partir desta noção o fonoaudiólogo poderia contribuir para a melhoria da relação entre Unidade de Saúde e população, desenvolvendo trabalhos sobre a relação linguagem e cultura. Como foi apresentado no decorrer deste estudo, os profissionais tem interesse em conhecer o contexto sobre o qual atuam, mas para transformar estes conhecimentos em parceria com a comunidade auxiliaria a compreensão de que a linguagem representa a maneira como as 
pessoas vivenciam, constróem, representam a realidade, enfim, como se constituem e se relacionam com o mundo.

Na Fonoaudiologia as dificuldades enfrentadas pela profissão para inserir-se no âmbito da Saúde Pública, é um discurso recorrente. As questões que este trabalho pode colocar para reflexão é que ainda conhecemos pouco o que quer dizer este público da saúde pública; lutamos para entender a saúde não como ausência de doença. Os movimentos propostos pelo trabalho etnográfico, podem ser muito úteis para a Fonoaudiologia, ao invés de ficarmos o tempo todo tentando provar que somos imprescindíveis a Saúde Pública, como se nossa inserção nos serviços fosse natural, realizando o jogo de espelhos proposto por esta metodologia poderíamos nos perguntar: o que temos a aprender com a Saúde Pública?

Ao respondermos esta questão descobriríamos mais sobre nós mesmos, evidenciando a necessidade da área em pensar numa Fonoaudiologia Social que construa reflexões sobre a linguagem e cultura no seu desenvolvimento histórico, social, cultural e interpessoal. Já que a Saúde Pública esta buscando não mais ser burocrática e fixa em planejamentos, intervenções, gerenciamento, levantamentos epidemiológicos, mas através do diálogo direto com a população busca construir-se a cada dia.

Cabe também pensar porque dos inúmeros empréstimos e interpelações a outras áreas que a fonoaudiologia tem realizado, ainda não é expressiva a aproximação com áreas como a psicologia social, história social e psicanálise social disciplinas que também trabalham com a articulação cultura e cotidiano.

São inúmeras as questões da área a serem refletidas, já que construiu-se todo um arcabouço teórico- metodológico para atuação na dimensão individual ou em pequenos grupos. Espero que este trabalho possa contribuir para as discussões da área causando um desassossego ao pensarmos o quanto a 
partir de nossas práticas contribuímos para a exclusão, patologização e silenciamento da população. 


\section{Referências}

... . citar é continuar uma conversa do passado e dar contexto ao presente; citar é refletir sobre o que foi feito antes, pois, se não o fizermos, falamos no vácuo, onde a voz humana não faz som. 
ADORNO, Rubens C.F. e CASTRO, Ana Lúcia. O exercício da sensibilidade: pesquisa qualitativa e a saúde com a qualidade. Revista Saúde e Sociedade 1994; 3(2): 172-185.

ALVES, Paulo C. e RABELO, Míriam C. Repensando os estudos sobre representações e práticas em saúde/doença. Rio de Janeiro: FiocruzRelume Dumará,1998. Antropologia as saúde: traçando identidade e explorando fronteiras; p. 107-121.

ANDRADE, Claúdia R. F. Problemas Fonoaudiológicos. In: CONCEIÇÃO, J.A.N. (org.) Saúde escolar: a criança, a vida e a escola. São Paulo: Sarvier, 1994. Monografias Médicas, série pediatria, volume XXXIII. p.153.

ANDRADE, Claúdia R.F. Ações Fonoaudiológicas na Saúde Materno Infantil. São Paulo: Lovise,1996. Fonoaudiologia em Berçário Normal e de risco. p.25-42.

ATKINSON, Paul e HAMMERSLEY, Martyn. Ethnography and Participant Observation. In: DENZIN, Norman. K. e LINCOLN, Yvonna S. Handbook of qualitative research. London: SAGE,1994. p. 248.

BARTHES, Roland. O óbvio e o obtuso. Trad. De Léa Novaes. São Paulo: Nova Fronteira, 1990. p.217-230

BECKER, Howard S. Métodos de Pesquisa em Ciências Sociais. São Paulo: Hucitec,1993.

BERGER, Peter L. e LUCKMANN, Thomas. A construção social da realidade. $17^{\mathrm{a}} \mathrm{e}$ ed. Petropolis:Vozes, 1999. 
BERLINGUER, Giovanni. Questões de vida: ética, ciência, saúde. Trad. Maria Patrícia Sabóia Oirico e Mauro Porru. São Paulo: Hucitec, 1993. 149160.

BOLTANSKI, Luc. As classes sociais e o corpo. Tradução de Regina Machado. Rio de Janeiro: Graal,1979.

CANESQUI, Ana Maria. Dilemas e desafios das ciências sociais na saúde coletiva. São Paulo:Hucitec-Abrasco,1995.p.119-36.

CHAUÍ ,Marilena. Convite à Filosofia. São Paulo: Ática, 1994. p. 288-296.

CORDEIRO, Denise T. Da inclusão dos pais no atendimento fonoaudiológico de crianças com sintomas de linguagem: o que diz a literatura. São Paulo: 2000. [ Dissertação de Mestrado - Pontifícia Universidade Católica de São Paulo]

COSTA, Jurandir F. Ordem Médica e norma familiar. $2^{\frac{a}{a}}$ edição. Rio de Janeiro: Graal Editora, 1983.

COUTINHO, Ana Lúcia e RUDIGER, Catarina. Florianópolis, ilha açoriana. Florianópolis: Mares do Sul, 1998. Coleção Mares do Sul Cultura;5.

CUNHA, Maria Cláudia. O normal e o patológico em distúrbios da comunicação. São Paulo: 1986. [ Dissertação de Mestrado - Pontifícia Universidade Católica de São Paulo].

DA MATTA, Roberto. A casa @ a rua. 5ª̣ed. Rio de Janeiro:Rocco,1997.

FAUSTINO, Silvia. O lugar da linguagem na filosofia do século $X X$. In: FABBRINI,R. e OLIVEIRA, S. L. (org.) Interpretação. São Paulo: Lovise, 1998. Série Linguagem. no 3. p. 87 - 97. 
FERREIRA, Jaqueline. Cuidados do Corpo em vila de classe popular. In: DUARTE, Luiz Fernando D.(org.). Doença, sofrimento, perturbação: perspectivas etnográficas. Rio de Janeiro: FIOCRUZ, 1998.p.49 - 56.

FLORES, Maria Bernadete R. A farra do boi: palavras, sentidos, ficções. $2^{\mathrm{a}}$ ed. Florianópolis: Ed. da UFSC,1998.

GEERTZ, Clifford. A interpretação das Culturas. Rio de Janeiro: LTC,1989.

GEERTZ, Clifford. O saber local. 2 2ed. Petrópolis, Rio de Janeiro:Vozes, 1999.

GIDDENS, Anthony. As consequências da modernidade. São Paulo: Ed. da UNESP,1991.

GOMES, Ivone D. E quando a família vem ao caso. In: MARCHESAN, Irene e col. Tópicos em Fonoaudiologia 1995. São Paulo:Lovise,1995. Volume II. p. $483-496$

HABERMAS, Jurgen. Pensamento pós-metafísico: estudos filosóficos.

Trad. Flávio Siebeneichler. Rio de Janeiro: Tempo Brasileiro,1990.

HELMAN, Cecil G. Cultura, saúde e doença. $2^{a}$ ed. Porto Alegre: Artes Médicas, 1994.

HILGERT, Celso F. Perspectivas da Inserção da Fonoaudiologia no Programa Nacional de Saúde. In: Anais do Encontro Nacional de Fonoaudiologia Preventiva e Social. São Paulo: Conselho Regional de Fonoaudiologia 2ª região,1988. p. 11-13.

LANE, Silvia T. M. Linguagem, pensamento e representações sociais. $13^{\mathrm{a}}$ ed. São Paulo: Brasiliense, 1997. Psicologia Social. p. 32-39. 
LEAVELL, H.R. e CLARK, E.G. Medicina Preventiva. São Paulo: Mc GrawHill,1977.

LEONTIEV, Alexis. O desenvolvimento do psiquismo.1 ${ }^{\text {a }}$ ed. São Paulo: Moraes,1978.

LEWIS, Dóris R. A prática fonoaudiológica em serviços de atenção primária à saúde em São Paulo: um estudo de representações socias. São Paulo; 1996. [ Tese de Doutorado - Faculdade de Saúde Pública da USP].

LOPES, Stella Maris B. et all. Programa Universidade Solidária aplicado às comunidades pesqueiras artesanais do litoral centro-norte catarinense. Itajaí:1998. [ Relatório de Projeto de Extensão - ProPPEx. UNIVALI]

LOYOLA, M. A. Médicos e curandeiros: conflitos sociais e saúde. São Paulo: Difel,1983.

MAGNANI, José Gulherme. Quando o Campo é a cidade: fazendo antropologia na Metrópole. São Paulo: Edusp-Fapesp,1996.

MAIA, Suzana M. Repensando a Fonoaudiologia. Revista Distúrbios da Comunicação. São Paulo, EDUC, vol. 2, n 3/4, 1987

MAIA, Suzana M. Implicações sociais do trabalho fonoaudiológico na atenção primária à saúde. In: BEFI, Débora (org.). Fonoaudiologia na atenção primária à saúde. São Paulo:Lovise,1997.p.37-41.

MASSON, Maria Lúcia V. É melhor prevenir ou remediar? Um estudo sobre a construção do conceito de prevenção em fonoaudiologia. São Paulo; 1995. [ Dissertação de Mestrado - Pontifícia Universidade Católica de São Paulo]. 
MEDEIROS, Rodrigo P. Caracterização sócio-econômica e cultural das comunidades pesqueiras do litoral centro-norte catarinense. Itajaí:1995. [Relatório Final de Bolsa de Iniciação Científica - Universidade do Vale do Itajaí]

MENDES, Vera Lúcia F. Fonoaudiologia nas Unidades Básicas de Saúde: a relação com os usuários. São Paulo:1994. [ Dissertação de Mestrado - Pontifícia Universidade Católica de São Paulo].

MENDONÇA, Magaly. Evolução da ocupação da península de Zimbros. Florianópolis:1984. [ Monografia do Departamento de Geociências Universidade Federal de Santa Catarina].

MINAYO, Maria Cecília. O conceito de representações sociais dentro da sociologia clássica. In: GUARESCHI, Pedrinho e JOVCHELOVITCH, Sandra. Textos em representações sociais. $4^{\circledR}$ ed. Petropólis:Vozes, 1998. p.89-111.

MINAYO, Maria Cecília . O Desafio do Conhecimento. $5^{\mathrm{a}}$ ed. Rio de Janeiro: Hucitec - Abrasco, 1998 .

MOLINA - LOZA, Carlos A . Destino Familiar, Desatino Terapêutico. Belo Horizonte: ArteSã , 1996. p. $259-271$.

NUNES, Everardo D. As ciências sociais e a saúde: o pensamento recente de alguns pesquisadores. In: CANESQUI, Ana Maria. Dilemas e desafios das ciências sociais na saúde coletiva. São Paulo: Hucitec-ABRASCO, 1995. p. 53-62.

OLIVEIRA, Francisco J. A. de. Concepções de Doença: o que os serviços de saúde têm a ver com isso? In: DUARTE, LUIZ Fernando e LEAL, Ondina F. Doença, sofrimento, perturbação: perspectivas etnográficas. Rio de Janeiro: FIOCRUZ,1998. p. 81-94. 
OLIVEIRA, Sandra M.R.P. Maternidade: experiência com curso de psicoprofilaxia e triagem fonoaudiológica. In: ANDRADE, Cláudia C.R.F.(org.) . Fonoaudiologia em Berçário Normal e de risco. São Paulo: Lovise, 1996 .p.227-234

ORLANDI, Eni. Interpretação. Petrópolis:Vozes,1996.

PAIM, Heloisa H. S. Marcas no corpo: gravidez e maternidade em grupos populares. In: Duarte, L. F. e Leal, O. Doença, sofrimento, perturbação: perspectivas etnográficas. Rio de Janeiro: FIOCRUZ, 1998. p. 81-94.

PEREIRA, Cristiane M. Fonoaudiologia em atenção primária à saúde: a questão do sintoma na clínica fonoaudiológica. São Paulo;1998. [ Dissertação de Mestrado - Pontifícia Universidade Católica de São Paulo].

PERISSONOTO, Jacy. Atuação fonoaudiológica com o bebê prematuro: acompanhamento do desenvolvimento. In: ANDRADE, Cláudia C.R.F.(org.) Fonoaudiologia em Berçário Normal e de risco. São Paulo: Lovise,1996.p.129-148.

PROST, A . Fronteiras e espaços privado. In: História da vida privada 5 : da primeira guerra aos nossos dias. São Paulo: Cia das Letras, 1992. p. $61-154$.

QUEIROZ, Marcos S. Representação de doença e instituições de cura numa aldeia de pescadores. Campinas:1978. [Dissertação de Mestrado Instituto de Filosofia e Ciências Humanas da Universidade Estadual de Campinas] .

RODRIGUES, Núbia e CAROSO, Carlos A. Idéia de 'Sofrimento' e Representação Cultural da Doença na Construção da Pessoa. In: DUARTE, Luiz Fernando D. (org.) Doença, sofrimento, perturbação: perspectivas etnográficas. Rio de Janeiro: FIOCRUZ, 1998.p.137-150. 
RUBINO, Rejane. Entre ver e ler: o olhar do fonoaudiólogo em questão. In: LIER-DE VITTO, Maria Francisca. Fonoaudiologia: no sentido da linguagem. São Paulo: Cortez,1994. p. 69 - 90 .

SARTI, Cynthia. Porque usar técnicas etnográficas no mapeamento. Mimeo - não publicado,1998.

SEVERINO, José Roberto. Itajaí e a identidade açoriana: A maquiagem possível. Itajaí: Ed. da Univali,1999.

SILVA, Ana Paula B.V. Linguagem e cultura: a construção da norma culta no Brasil, 1920-1940. São Paulo:1999. [ Tese de Doutorado em História - Pontifícia Universidade Católica de São Paulo].

TANAKA, Cíntia e MESSAS, Cristiane. UTI Neonatal: experiência fonoaudiológica em um Hospital e Pronto-Socorro Infantil. In: ANDRADE, Cláudia C.R.F.(org.) . Fonoaudiologia em Berçário Normal e de risco. São Paulo: Lovise,1996 p.259-268

VASCONCELLOS, Maria da Penha C. Os (des) caminhos da formação sanitária e os direitos sociais: uma reflexão à partir da Escola de Saúde de Minas Gerais. São Paulo;2000. [ Tese de Doutorado - Faculdade de Saúde Pública da Universidade de São Paulo]

WITTER, Geraldine. Implicações sociais da linguagem. In: Anais do Encontro Nacional de Fonoaudiologia Preventiva e Social. São Paulo: Conselho Regional de Fonoaudiologia $2^{\text {a }}$ região,1988.

WITTGENSTEIN, Ludiwig. Investigações Filosóficas. Trad. José Carlos Bruni. São Paulo:Nova Cultural,1996. 